\title{
Assessment of Shallow Groundwater Purification Processes after the Construction of a Municipal Sewerage Network
}

\author{
Tamás Mester ${ }^{1, *(\mathbb{D}, \text { György Szabó }}{ }^{1}$ and Dániel Balla ${ }^{2, *(\mathbb{D}}$ \\ 1 Department of Landscape Protection and Environmental Geography, University of Debrecen, \\ 4032 Debrecen, Hungary; szabo.gyorgy@science.unideb.hu \\ 2 Department of Computer Graphics and Image Processing, University of Debrecen, 4028 Debrecen, Hungary \\ * Correspondence: mester.tamas@science.unideb.hu (T.M.); balla.daniel@inf.unideb.hu (D.B.)
}

check for updates

Citation: Mester, T.; Szabó, G.; Balla, D. Assessment of Shallow Groundwater Purification Processes after the Construction of a Municipal Sewerage Network. Water 2021, 13, 1946. https://doi.org/10.3390/w13 141946

Academic Editor: Dimitrios E. Alexakis

Received: 23 June 2021

Accepted: 12 July 2021

Published: 15 July 2021

Publisher's Note: MDPI stays neutral with regard to jurisdictional claims in published maps and institutional affiliations.

Copyright: (c) 2021 by the authors. Licensee MDPI, Basel, Switzerland. This article is an open access article distributed under the terms and conditions of the Creative Commons Attribution (CC BY) license (https:// creativecommons.org/licenses/by/ $4.0 /)$.

\begin{abstract}
In the present study, the impact of the construction of the sewerage network (2014) on groundwater quality was studied on the example of a middle-sized settlement in the Great Hungarian Plain and changes in water quality were assessed using GIS and multivariate statistical analysis. As a result of the pollution that has been going on for decades, the groundwater supply of the municipality has become heavily polluted. In the period before sewerage (2011-2013), clear spatial differences were shown in the degree of contamination in the area of the settlement: the degree of contamination increased in the direction of local groundwater flow. Based on our results, the construction of the sewerage network resulted in marked changes in the quality of groundwater wells. Our studies showed a clear decrease in the concentrations of inorganic pollutants $\left(\mathrm{NH}_{4}{ }^{+}\right.$, $\mathrm{NO}_{2}{ }^{-}, \mathrm{NO}_{3}{ }^{-}, \mathrm{PO}_{4}{ }^{3-}$ ). In the fifth year of the post-sewerage period (2019), the clear spatial difference between wells was eliminated. We have observed a strong descent (1.5 to $2 \mathrm{~m}$ ) in groundwater levels in the post-sewerage period, the reason for that is clearly due to that wastewater outflow was eliminated. On this basis, it can be declared that the purification processes in the area have started, but at the same time, our results show that pollutants entering environment undergo a number of transformations and remain in the system for a long time.
\end{abstract}

Keywords: groundwater quality; environmental pollution; cleaning process; sewerage network; GIS; multivariate statistical analysis

\section{Introduction}

In parallel with the construction of the drinking water network, the sewerage network and wastewater treatment plants were not established in many countries around the world, therefore municipal wastewater from households is stored in various installations without insulation in the yard of households (cesspits, soakaways, septic tanks) became a widespread practice [1-5]. Wastewater flowing out of these point sources resulted in a sharp degradation of the groundwater supply in the municipalities [6-9].

However, the deterioration of groundwater status occurred not only in Hungary, it is a global problem, which has thus become the focal point of environmental research [10]. Numerous studies show that, in addition to industrial and agricultural activity, one of the most significant sources of pollution is municipal wastewater, the treatment and cleaning of which is often unresolved in developing and developed countries alike [11-13]. In the more developed urban environment, wastewater exfiltration from the sewer system poses a threat to the subsurface water resources [14].

Nitrogen loading to groundwater in rural and urban areas, mainly from domestic sewage leaching, has become an increasingly important environmental problem in recent years $[15,16]$. Nitrogen can enter the groundwater system in various organic and inorganic forms and, due to its solubility, it leaches easily from the point of infiltration into deeper aquifers, causing contamination $[17,18]$. Lack of wastewater treatment has led to widespread nitrogen contamination of groundwater systems not only in less developed 
regions of the world, but also in developed regions [19]. In the municipal environment, organic phosphorus from uninsulated sewage tanks and pit latrines leaks into the soil and groundwater in large quantities, causing very serious pollution $[20,21]$. Human metabolism processes contribute $\sim 2 \mathrm{~g} /$ day, and detergents used contribute a further $\sim 2 \mathrm{~g} /$ day of phosphorus load [22].

Preserving and improving groundwater quality in the urban environment is a complex task due to the many sources of pollution [23-25]. Although groundwater monitoring is of great interest to water decision-makers for establishing strategies to protect water resources, due to the high costs there is not enough data available at a sufficient level of detail, especially for long-term monitoring [26,27]. For this reason, only few studies have been conducted to assess the impact of the sewerage network on groundwater $[28,29]$. In addition, knowledge of the baseline condition is necessary to assess the changes, but most municipalities do not have such a settlement-wide data making comparative analysis impossible. One of the aims of our study is to fill this scientific gap.

Assessment of groundwater quality is crucial for environmental management and land development $[30,31]$. A complex analysis not only presents the water chemistry parameters, but also combines the results of water quality index (WQI), geographic information system (GIS) and statistical analysis, with a strong emphasis on the mapping and interpretation of environmental data, which is of great importance in environmental science and environmental policy as well [32-35].

Multivariate statistical methods are a valuable tool for assessing spatial and temporal differences, interpreting complex water quality datasets, identifying the source of pollutants (natural or anthropogenic), and assisting in the design of monitoring networks, effective water management and possible practical solutions for pollution remediation [36]. Comprehensive groundwater quality studies using multivariate statistical analyses have been carried out in a number of studies. Demirel and Güler (2006) identified anthropogenic factors affecting groundwater body chemistry in the coastal zone of the Mersin-Erdemli basin using hierarchical cluster analysis (HCA), principal component analysis (PCA) and geochemical modelling techniques [37]. Results showed that seasonal variations are caused by fertilizer application in the early summer period. Cloutier and colleagues (2008) used PCA and HCA to make the large dataset available transparent and to identify processes that determine the geochemical properties of groundwater [38]. Yidana and colleagues (2010) used hierarchical cluster analysis in addition to traditional graphical representation to isolate groundwater bodies with different salinity in southwestern Ghana [39]. Cluster analysis proved to be an effective statistical tool, allowing the grouping of elements with similar properties into correlation pairs. Lin and colleagues (2012) investigated the factors influencing the temporal variability and chemical composition of near-surface groundwater in Manukan Island, Malaysia. By using analysis of variance, PCA, HCA and other geostatistical techniques, they found that near-surface groundwater is unsuitable for use as drinking water [40]. Farsang and colleagues (2017) investigated 12 inorganic contaminants in the groundwater of the city of Szeged. Discriminant analysis was used to evaluate spatial variations in groundwater quality, and R/S analysis was used to investigate water level fluctuations in the groundwater system and the Tisza River [41].

Hungary ratified the 2000/60/EC Water Framework Directive and Directive 91/271/EEC on urban wastewater treatment by joining the European Union, in accordance with which the establishment of the sewerage network of municipalities with pollutant loads above 2000 inhabitant equivalents (IE) is currently ongoing. Very significant progress has been made in the collection and purification of municipal wastewater in Hungary in the last decade. The difference in the proportion of homes connected to the water and sewerage decreased from $41.1 \%$ in 2000 to $12.3 \%$ in 2019 [ 42 ].

As a result of the investments realised, the amount of municipal wastewater entering the groundwater system has been significantly reduced, the effect of which extends to the entire urban environment $[43,44]$. Since the construction of a sewerage network is a very heavy financial burden for municipalities, the question may arise as to the benefits of 
these investments. Does it really solve the problems and, if so, how quickly do the desired positive changes occur? In order to accurately determine the extent, intensity and duration of the expected purification processes, long-term groundwater monitoring is essential, during which a pre-investment baseline assessment is required.

In the present study, the impact of the construction of the sewerage network on groundwater quality was studied on the example of Báránd a middle-sized settlement in the Great Hungarian Plain and changes in water quality were assessed. Regular water quality tests have been carried out in the village since 2011, which have continued after the construction of the sewerage network municipality in 2014 and are still ongoing. In addition, groundwater monitoring, which has been going on for a decade, provides an opportunity to carry out a complex, comparative research that can not only bring important value added for both domestic and international literature, but also has economic importance.

\section{Materials and Methods}

\subsection{Site Location and Characteristics}

The investigated settlement Báránd is located in the eastern part of the Great Hungarian Plain, in the Nagy-Sárrét region on the western part of the alluvial deposit of the Sebes-Körös River (Figure 1), and has a population of 2567 [45].

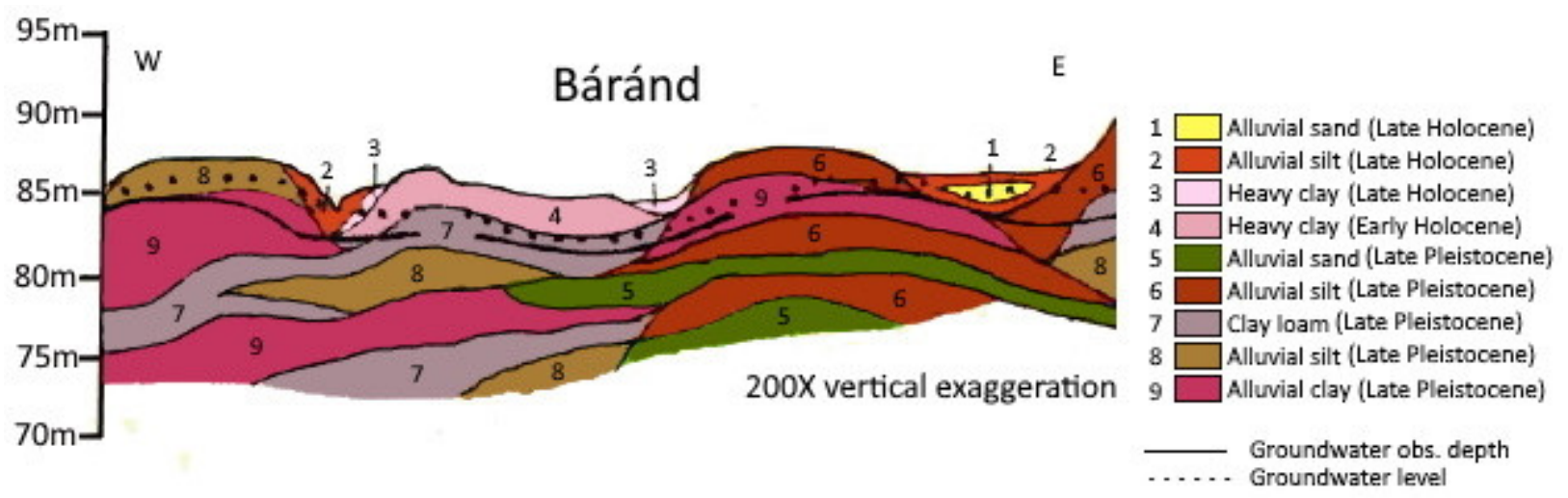

Figure 1. Geological cross section of the study area (Modified based on Rónai 1980 [46]).

The altitude of the Nagy-Sárrét is typically $85-89 \mathrm{~m}$, and the region is classified as a flat plain (relative relief $0-3 \mathrm{~m} / \mathrm{km}^{2}$ ). The groundwater level can be found close to the surface, at a depth of 1-2 m; consequently, all the soil types have been formed under the influence of water [47]. In the study area, the most frequent soil types are Solonetz, Vertisol, Kastenozem, and Chernozem, and in the built-up area-as a result of anthropogenic effects-Technosol [48].

The annual water production of the settlement has been between $90,000-120,000 \mathrm{~m}^{3}$ in the last decade, the amount of water supplied to households was $70,000-90,000 \mathrm{~m}^{3}$. According to our calculations, $40-60 \%$ of the municipal wastewater stored in uninsulated sewage tanks could have leaked into the soil, which meant $30,000-55,000 \mathrm{~m}^{3}$ of leaking wastewater per year at the municipal level in the pre-sewerage period. Since the municipality has sewage discharges of more than 2000 inhabitants equivalent, a sewerage system was constructed in 2014 in accordance with the relevant legislation.

\subsection{Field Sampling and Laboratory Analysis}

In the present study an analysis of the water samples collected before $(2011,2012,2013)$ and after $(2017,2018,2019)$ the construction of the sewerage network (2014) was performed. The number of wells has been extended to 40 from 2013 during summer sampling in order to determine the contamination as accurately as possible in space (Figure 2). The base depth of the monitoring wells ranged from 6 to $10 \mathrm{~m}$. 


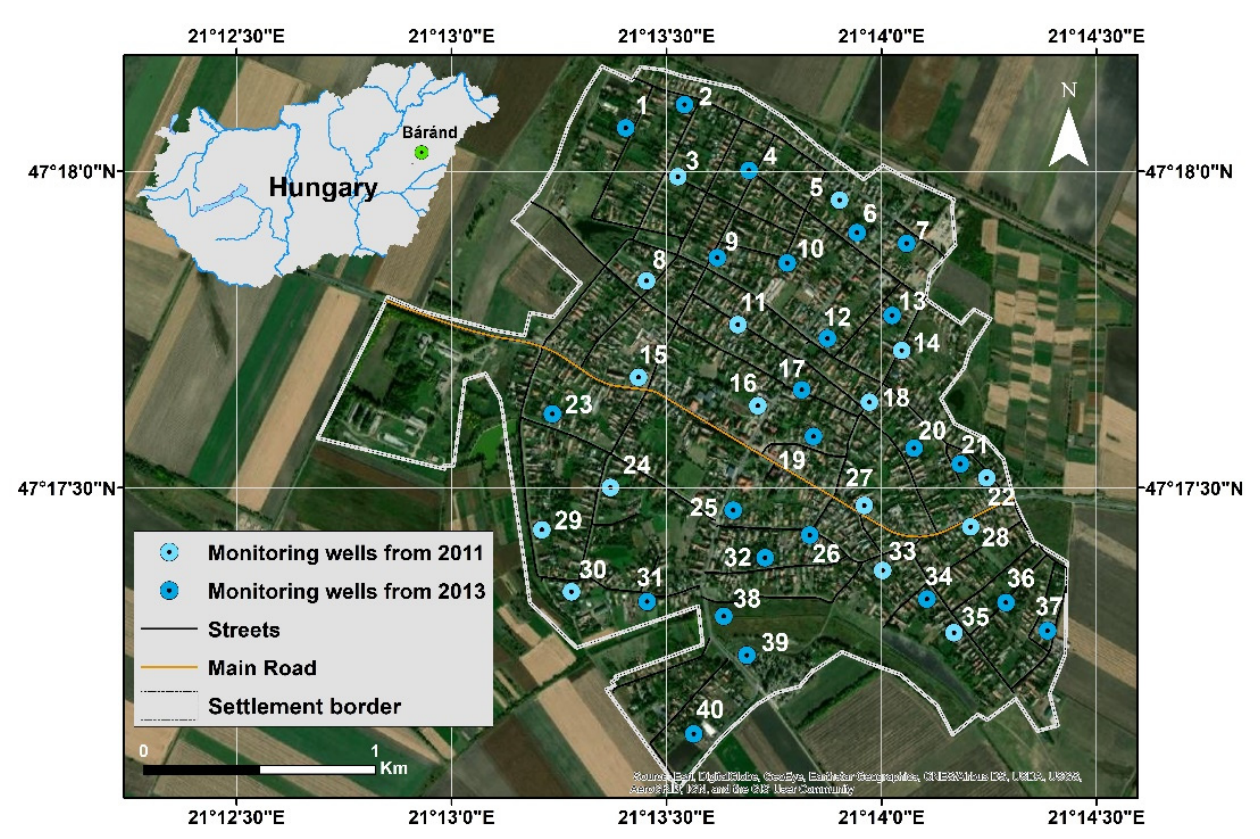

Figure 2. Location of the monitoring wells in the investigated settlement in Hungary.

The most characteristic pollutants of municipal wastewater were included in the analysis. The ammonium ion $\left(\mathrm{NH}_{4}{ }^{+}\right)$, nitrite ion $\left(\mathrm{NO}_{2}{ }^{-}\right)$, nitrate ion $\left(\mathrm{NO}_{3}{ }^{-}\right)$, orthophosphate ion $\left(\mathrm{PO}_{4}{ }^{3-}\right)$ and organic matter (COD) content of the water samples taken were determined on the basis of the Hungarian Standards (HS ISO 7150-1:1992, HS 448-18:2009, HS 1484-13:2009, HS 12750-17:1974) in the Complex Laboratory of the Institute of Earth Sciences, University of Debrecen. Chloride ion $\left(\mathrm{Cl}^{-}\right)$sulphate-ion $\left(\mathrm{SO}_{4}{ }^{2-}\right)$, p- and m-alkalinity $\left(\mathrm{HCO}_{3}{ }^{-} / \mathrm{CO}_{3}{ }^{-}\right)$ have been defined in the post-sewerage period on the basis of the Hungarian standards (HS 1484-15:2009, HS 260-7:1987, HS 448-11:1986). The sodium ion $\left(\mathrm{Na}^{+}\right)$content of the water samples was measured regularly, magnesium $\left(\mathrm{Mg}^{2+}\right)$ calcium $\left(\mathrm{Ca}^{2+}\right)$ and potassium $\left(\mathrm{K}^{+}\right)$ion was measured in the post-sewerage period using a PERKIN ELMER 300 atomic absorption device. Data quality for major components was estimated by charge balance [49]. Deviation between the sum of concentrations of major cations and the sum of concentrations of major anions, in equivalent units, varies between $-5 \%$ and $+5 \%$. The $\mathrm{pH}$ and EC values were determined using a WTW 315i and CONSORT C3010 measuring instruments. The results were assessed on the basis of the relevant limits of the Joint Regulation KvVM-EüM-FVM No 6/2009 (IV. 14). The cation and anion composition of the water samples from the post-sewerage period was evaluated using Piper and Durov diagrams generated with Grapher 17 software.

The results of field measurements with a Trimble S9 GPS device to create digital elevation models for the surroundings of the municipality to determine the absolute height of groundwater levels (Figure 3).

\subsection{Statistical Analysis and GIS}

Geographical information system (GIS) applications are widely used to determine the spatial distribution of groundwater quality parameters by integrating spatial data with other geographical information [50-53]. The geovisualization of the results was performed with ArcGIS 10.4.1 software, the spatial distribution of the contaminants with Kriging interpolation using the software Surfer 19. In environmental sciences, interpolation can be considered as primary form of geostatistical analysis, which is often used to predict values in unobserved locations based on the values in observed locations. Ordinary kriging, a type of interpolation has become a widely used interpolation method for assessment of 
spatial variation of groundwater quality [54]. A semivariogram can be used to quantify spatial dependence:

$$
\gamma(h)=\frac{1}{2 N(h)} \sum_{i=1}^{N(h)}[Z(X i+h)-Z(X i)]
$$

where $\gamma(h)$ illustrates the semivariogram as a function of the lag distance or separation vector $h$ between two points. $N(h)$ represents the number of observation pairs divided by distance $h$, and $Z(X i)$ represents the random variable at position $X i$ [55].

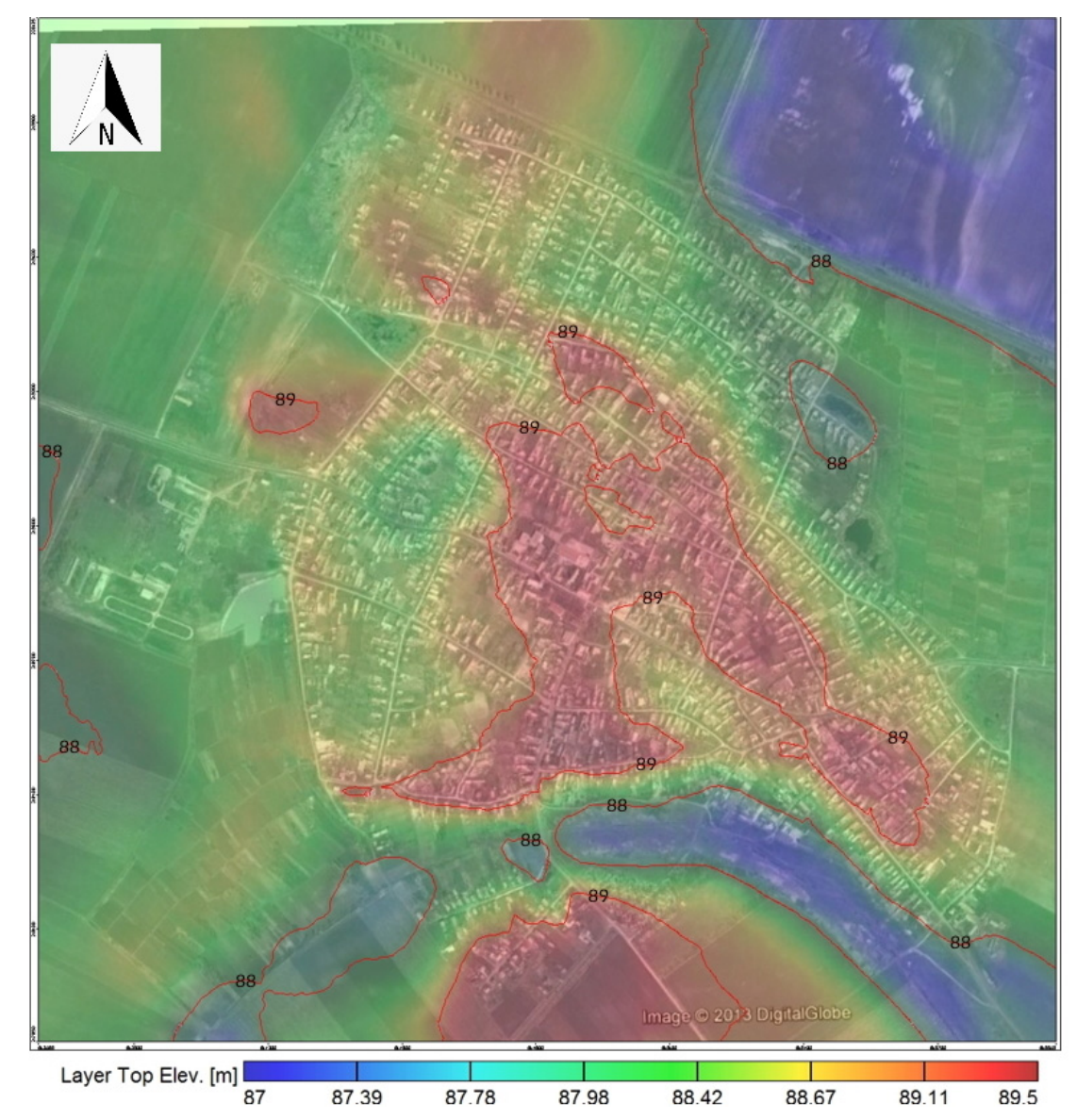

Figure 3. Digital relief map of the investigated settlement.

Ordinary Kriging is a linear appropriate interpolation technique with which interpolated (predictive) maps can be created. The spatial distribution of different parameters can be determined according to the equation below [56]:

$$
\hat{Z}(X 0)=\sum_{i=1}^{n} n \lambda i Z(X i)
$$

where $\hat{Z}(X 0)$ is the predictable value at $X 0$ points, while $\mathrm{n}$ is the number of the sampled point $Z(X i)$ is the recognized value at sampled $X i$ points, and $\lambda$ is the weight assigned to the sampled point.

The software IBM SPSS 22 was used to perform statistical processing of the data series and to represent the results. In addition to calculating the base statistical values, the normality of the series was examined as well. In addition to the calculation of the basic statistical values, mean, lower, upper quartile, mode, median and standard deviation, the results were plotted on different scatterplot and boxplot diagrams for better illustration. This is because boxplot diagrams are suitable for plotting interquartile range, median, highest and lowest values. In order to determine the strength of the relationship between the variables, 
Spearman's rank correlation test was performed. Principal component analyses were been performed to organize the variables into components and to better explore geochemical background processes. In addition, the results of the principal component analysis were used to investigate the spatial separability of monitoring wells. The number of principal components was determined based on the Kaiser criterion [57]. The suitability of the data for analysis was reported by Kaiser-Meyer-Olkin (KMO) and Bartlett probes. If the KMO value is higher than 0.5 and in the case of the Bartlett test $p<0.05$, then the database is suitable for the study. A hierarchic (Ward method) and two-stage cluster analysis were carried out to separate groundwater wells with similar characteristics from each other. Discriminant analyses were carried out to determine whether conditions before and after the construction of the sewerage network can be separated or not. The test was performed using the Wilks 'Lambda method. Fisher's (1936) two-group discriminant analysis is suitable for distinguishing between different groups [58].

\section{Results and Discussion}

\subsection{Water Quality before the Construction of the Sewerage Network}

According to our calculations, $40-50 \%$ of the municipal wastewater leaked from uninsulated septic tanks into the groundwater, which meant an annual raw sewage load of 50,000-60,000 $\mathrm{m}^{3}$. As a result of the pollution that has been going on for decades, the groundwater supply of the municipality has become heavily polluted. Anthropogenic effects were detected for all groundwater wells during sampling before the construction of the sewerage network. The statistical summary of the parameters investigated between 2011-2019 are shown in Table 1. To obtain a more detailed picture of the changes in the degree of contamination, we plotted the $\mathrm{EC}, \mathrm{NH}_{4}{ }^{+}, \mathrm{NO}_{3}{ }^{-}, \mathrm{PO}_{4}{ }^{3-}$ values of each well on a boxplot diagram (Figure 4).
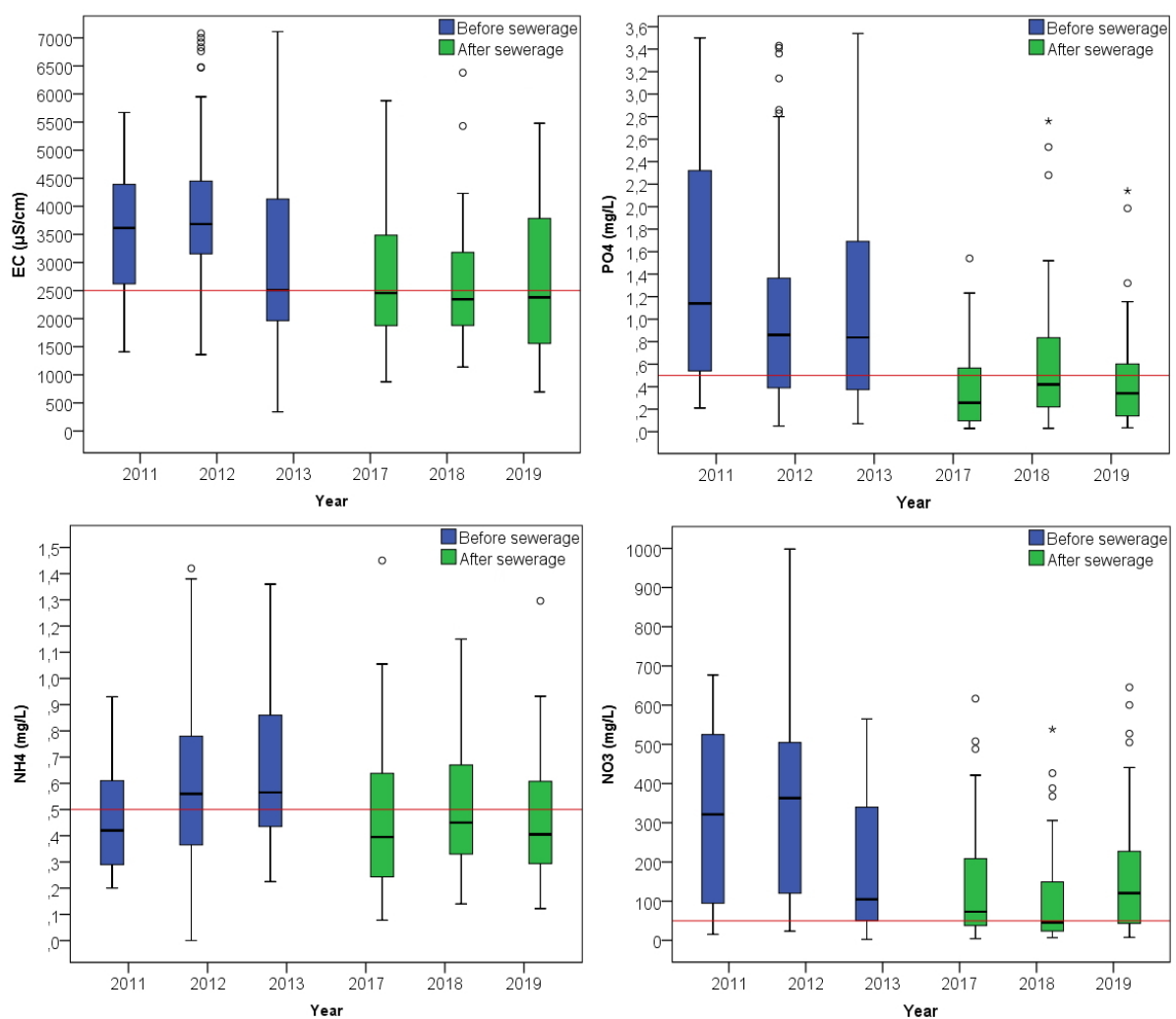

Figure 4. Box plots of $\mathrm{EC}, \mathrm{PO}_{4}{ }^{3-}, \mathrm{NH}_{4}{ }^{+}$and $\mathrm{NO}_{3}{ }^{-}$before and after the establishment of the sewerage network. The bottom and top of each box represent the lower and upper quartiles, and the line inside each box represents the median. The red line indicates the contamination limit value. 
Table 1. Descriptive statistics of the examined hydrochemical parameters. (+) indicates positive changes compared to the 2013 reference year, $(-)$ indicates negative changes based on the contamination limit for the given parameter.

\begin{tabular}{|c|c|c|c|c|c|c|c|c|c|c|c|c|}
\hline \multirow{2}{*}{ Parameter } & \multicolumn{8}{|c|}{ Mean } & \multicolumn{4}{|c|}{ St. Deviation } \\
\hline & 2011 & 2012 & 2013 & 2017 & 2018 & 2019 & 2011 & 2012 & 2013 & 2017 & 2018 & 2019 \\
\hline $\mathrm{pH}$ & 7.83 & 7.76 & 8.25 & 7.51 & 7.99 & 7.26 & 0.257 & 0.275 & 0.457 & 0.301 & 0.417 & 0.351 \\
\hline $\mathrm{EC}(\mu \mathrm{S} / \mathrm{cm})$ & 3524 & 3877 & 3032 & $2845(+)$ & $2637(+)$ & $2726(+)$ & 1194 & 1280 & 1701 & 1785 & 1136 & 1567 \\
\hline $\mathrm{NH}_{4}{ }^{+}(\mathrm{mg} / \mathrm{L})$ & 0.539 & 0.609 & 0.691 & $0.529(+)$ & $0.653(+)$ & $0.512(+)$ & 0.288 & 0.337 & 0.373 & 0.545 & 0.773 & 0.505 \\
\hline $\mathrm{NO}_{2}{ }^{-}(\mathrm{mg} / \mathrm{L})$ & 0.269 & 0.265 & 0.306 & $0.204(+)$ & $0.211(+)$ & $0.267(+)$ & 0.24 & 0.36 & 0.33 & 0.40 & 0.29 & 0.42 \\
\hline $\mathrm{NO}_{3}-(\mathrm{mg} / \mathrm{L})$ & 327.1 & 361.9 & 187.8 & $142.7(+)$ & $109.8(+)$ & $163.5(+)$ & 217.4 & 266.5 & 164.4 & 159.3 & 129.5 & 170.7 \\
\hline $\mathrm{PO}_{4}{ }^{3-}(\mathrm{mg} / \mathrm{L})$ & 1.36 & 1.12 & 1.22 & $0.39(+)$ & $0.65(+)$ & $0.49(+)$ & 0.93 & 0.78 & 1.09 & 0.39 & 0.65 & 0.49 \\
\hline $\mathrm{COD}(\mathrm{mg} / \mathrm{L})$ & 5.14 & 5.49 & 6.85 & $7.65(-)$ & $7.16(-)$ & $7.62(-)$ & 1.94 & 1.85 & 3.94 & 3.23 & 5.78 & 3.76 \\
\hline $\mathrm{Na}(\mathrm{mg} / \mathrm{L})$ & 424.6 & 361.8 & 237.9 & $377.9(-)$ & $352.4(-)$ & $379.3(-)$ & 285.9 & 213.5 & 141.7 & 389.6 & 298.6 & 330.1 \\
\hline \multirow{2}{*}{ Parameter } & \multicolumn{8}{|c|}{ Minimum } & \multicolumn{4}{|c|}{ Maximum } \\
\hline & 2011 & 2012 & 2013 & 2017 & 2018 & 2019 & 2011 & 2012 & 2013 & 2017 & 2018 & 2019 \\
\hline $\mathrm{pH}$ & 7.24 & 7.01 & 7.23 & 7.02 & 7.21 & 6.81 & 8.39 & 8.44 & 9.42 & 8.3 & 8.87 & 8.25 \\
\hline $\mathrm{EC}(\mu \mathrm{S} / \mathrm{cm})$ & 1410 & 1360 & 340 & $876(-)$ & $1140(-)$ & $695(-)$ & 5670 & 7080 & 7670 & $9290(-)$ & $6380(+)$ & $8910(-)$ \\
\hline $\mathrm{NH}_{4}^{+}(\mathrm{mg} / \mathrm{L})$ & 0.2 & 0.211 & 0.225 & $0.078(+)$ & $0.140(+)$ & $0.122(+)$ & 1.81 & 2.13 & 1.89 & $3.42(-)$ & $3.97(-)$ & $3.36(-)$ \\
\hline $\mathrm{NO}_{2}{ }^{-}(\mathrm{mg} / \mathrm{L})$ & 0.015 & 0.013 & 0.017 & $0.006(+)$ & $0.000(+)$ & $0.001(+)$ & 1.36 & 1.61 & 1.28 & $1.86(-)$ & $1.37(-)$ & $1.94(-)$ \\
\hline $\mathrm{NO}_{3}{ }^{-}(\mathrm{mg} / \mathrm{L})$ & 15.38 & 23.35 & 8.36 & $4.46(+)$ & $6.95(+)$ & $7.61(+)$ & 676.8 & 1140 & 564.8 & $616.6(-)$ & $538.3(+)$ & $645.5(-)$ \\
\hline $\mathrm{PO}_{4}{ }^{3-}(\mathrm{mg} / \mathrm{L})$ & 0.21 & 0.05 & 0.07 & $0.03(+)$ & $0.03(+)$ & $0.04(+)$ & 3.52 & 3.43 & 4.07 & $1.54(+)$ & $2.76(+)$ & $2.14(+)$ \\
\hline $\mathrm{COD}(\mathrm{mg} / \mathrm{L})$ & 1.84 & 1.68 & 2.40 & $2.90(-)$ & $1.1(+)$ & $1.66(+)$ & 9.36 & 10.29 & 18.20 & $17.68(+)$ & $36.8(-)$ & $16.65(+)$ \\
\hline $\mathrm{Na}(\mathrm{mg} / \mathrm{L})$ & 14.35 & 14.1 & 8.90 & $75.8(-)$ & $97.4(-)$ & $52.1(-)$ & 1120 & 1485 & 653.2 & $2254(-)$ & $1828(-)$ & $2019(-)$ \\
\hline \multirow{2}{*}{ Parameter } & \multicolumn{8}{|c|}{ Lower Quartile } & \multicolumn{4}{|c|}{ Upper Quartile } \\
\hline & 2011 & 2012 & 2013 & 2017 & 2018 & 2019 & 2011 & 2012 & 2013 & 2017 & 2018 & 2019 \\
\hline $\mathrm{pH}$ & 7.65 & 7.56 & 7.92 & 7.29 & 7.68 & 6.96 & 8.01 & 7.91 & 8.56 & 7.74 & 8.29 & 7.41 \\
\hline $\mathrm{EC}(\mu \mathrm{S} / \mathrm{cm})$ & 2585 & 3152 & 1950 & $1871(+)$ & $1874(+)$ & $1511(+)$ & 4395 & 4515 & 4310 & $3507(+)$ & $3190(+)$ & $3792(+)$ \\
\hline $\mathrm{NH}_{4}^{+}(\mathrm{mg} / \mathrm{L})$ & 0.29 & 0.36 & 0.43 & $0.243(+)$ & $0.325(+)$ & $0.289(+)$ & 0.61 & 0.785 & 0.865 & $0.643(+)$ & $0.680(+)$ & $0.617(+)$ \\
\hline $\mathrm{NO}_{2}{ }^{-}(\mathrm{mg} / \mathrm{L})$ & 0.03 & 0.04 & 0.052 & $0.021(+)$ & $0.009(+)$ & $0.024(+)$ & 0.32 & 0.297 & 0.416 & $0.167(+)$ & $0.300(+)$ & $0.308(+)$ \\
\hline $\mathrm{NO}_{3}-(\mathrm{mg} / \mathrm{L})$ & 94.41 & 119.3 & 50.16 & $37.65(+)$ & $23.72(+)$ & $43.09(+)$ & 527.6 & 507.1 & 341.7 & $221.1(+)$ & $153.1(+)$ & $244.8(+)$ \\
\hline $\mathrm{PO}_{4}{ }^{3-}(\mathrm{mg} / \mathrm{L})$ & 0.54 & 0.385 & 0.374 & $0.095(+)$ & $0.215(+)$ & $0.137(+)$ & 2.35 & 1.67 & 1.75 & $0.577(+)$ & $0.863(+)$ & $0.604(+)$ \\
\hline $\mathrm{COD}(\mathrm{mg} / \mathrm{L})$ & 3.58 & 3.54 & 4.02 & $5.24(-)$ & $3.59(+)$ & $4.57(-)$ & 6.57 & 6.29 & 8.05 & $9.89(-)$ & $8.48(-)$ & $10.1(-)$ \\
\hline $\mathrm{Na}(\mathrm{mg} / \mathrm{L})$ & 209.1 & 215.1 & 132.2 & $154.1(-)$ & $182.4(-)$ & $185.4(-)$ & 645.2 & 395.6 & 312.8 & $422.5(-)$ & $447.8(-)$ & $477.9(-)$ \\
\hline
\end{tabular}

The presence of $\mathrm{NH}_{4}{ }^{+}$indicates the decomposition of the organic matter content of the waters, which indirectly refers to wastewater load and fresh contamination. In the period before sewerage the mean of $\mathrm{NH}_{4}{ }^{+}$concentrations $(0.61 \mathrm{mg} / \mathrm{L})$ and the upper quartile $(0.78 \mathrm{mg} / \mathrm{L})$ exceeded the contamination limit $(0.5 \mathrm{mg} / \mathrm{L})$. In the vast majority of the wells, $\mathrm{NO}_{3}{ }^{-}$concentrations several times above the limit value $(50 \mathrm{mg} / \mathrm{L})$ were measured. The lower quartile value $(94.6 \mathrm{mg} / \mathrm{L})$ was more than double that of the limit while the upper quartile $(493.2 \mathrm{mg} / \mathrm{L})$ was nearly 10 times higher than the limit. $\mathrm{PO}_{4}{ }^{3-}$ concentrations also show the strong contamination of groundwater. In $72.2 \%$ of the measurements before the construction of the sewerage network concentrations above the relevant contamination limit of $0.5 \mathrm{mg} / \mathrm{L}$ were found. The total ion content in the studied groundwater wells exceeded or significantly exceeded the limit of $2500 \mu \mathrm{S} / \mathrm{cm}$ in the majority of wells. The mean value of the data series was $3637 \mu \mathrm{S} / \mathrm{cm}$ and the upper quartile value was $4395 \mu \mathrm{S} / \mathrm{cm}$. The mean $\mathrm{Na}^{+}$concentration was nearly twice the limit value $(200 \mathrm{mg} / \mathrm{L})$. Significant differences in spatial concentration trends suggest that, in addition to soil factors, concentrations were largely influenced by the typically high sodium content of communal wastewaters. Concentrations exceeding the limit value for COD contamination $(4.5 \mathrm{mg} / \mathrm{L})$ were measured in $71 \%$ of the wells.

These results are consistent with the results of other studies carried out in a village environment which showed strong pollution of the groundwater resources of the settlements [59-62].

\subsection{Water Quality Changes after the Construction of the Sewerage Network}

Examining the data series for the period before (2011-2013) and after (2017-2019) the construction of the sewerage network significant positive changes in groundwater quality were shown using various geoinformatic and statistical methods. Our studies showed a clear decrease in the concentrations of inorganic pollutants $\left(\mathrm{NH}_{4}{ }^{+}, \mathrm{NO}_{2}{ }^{-}, \mathrm{NO}_{3}{ }^{-}, \mathrm{PO}_{4}{ }^{3-}\right)$ (Table 1) (Figure 4). 
Although the average values of $\mathrm{NH}_{4}{ }^{+}$concentrations continued to be above the limit value in each studied year, a steady decreasing trend can be observed. While concentration over $1 \mathrm{mg} / \mathrm{L}$ was measured in $17.5 \%$ of the wells in large sample 2013, only such concentrations were measured in only $5 \%$ of the wells in $2019 . \mathrm{NO}_{2}{ }^{-}$concentrations also decreased to a detectable extent, from an average value of $0.416 \mathrm{mg} / \mathrm{L}$ in 2013 to $0.308 \mathrm{mg} / \mathrm{L}$ in 2019 . The decrease in the concentration of $\mathrm{NO}_{3}{ }^{-}$also indicates the loss of a significant part of the contaminant supply, as the average value decreased from $187.8 \mathrm{mg} / \mathrm{L}$ (2013) to $109.8 \mathrm{mg} / \mathrm{L}$ in 2018. The lower quartile value was below the limit value during each large sampling of the period after the construction of the sewerage network. The average $\mathrm{PO}_{4}{ }^{3-}$ concentration in 2019 decreased by $60 \%$ compared to the reference year 2013, reducing it to the level of the contamination limit $(0.5 \mathrm{mg} / \mathrm{L})$. In $32.5 \%$ of the wells concentrations above the limit were measured in 2019 compared to $65 \%$ in 2013. In the fifth year following construction of the sewerage network, the proportion of the areas of the municipality where the EC value was below the limit value $(2500 \mu \mathrm{S} / \mathrm{cm})$ increased compared to the reference year.

\subsection{Results of the Discriminant Analysis}

A discriminant analysis was performed to determine whether the water chemistry parameters indicate whether the sample was taken before or after sewerage. In order to determine this, the data series were categorised into pre-sewerage (2011-2013) and post-sewerage (2017-2019) and discriminant analysis was performed (Table 2). The WilksLambda test showed a significant result $(p<0.001)$. A total of $85.6 \%$ of the cross-validated values were successfully classified into their original category. Applying discriminant analysis, it can be determined with $82.4 \%$ probability whether the sample is from the period prior to or after the establishment of the sewerage network (Table 2). On this basis, the construction of the sewerage network resulted in marked changes in the quality of groundwater wells.

Table 2. Classification results of the discriminant analysis.

\begin{tabular}{|c|c|c|c|c|c|}
\hline \multicolumn{6}{|c|}{ Classification Results ${ }^{a, c}$} \\
\hline & & \multirow{2}{*}{ Sewerage Status } & \multicolumn{2}{|c|}{ Predicted Group Membership } & \multirow{2}{*}{ Total } \\
\hline & & & 1 & 2 & \\
\hline \multirow{4}{*}{ Original } & \multirow{2}{*}{ Count } & Before sewerage & 175 & 23 & 198 \\
\hline & & After sewerage & 29 & 91 & 120 \\
\hline & \multirow{2}{*}{$\%$} & Before sewerage & 88.4 & 11.6 & 100.0 \\
\hline & & After sewerage & 24.2 & 75.8 & 100.0 \\
\hline \multirow{4}{*}{ Cross-validated $^{\mathrm{b}}$} & \multirow{2}{*}{ Count } & Before sewerage & 173 & 25 & 198 \\
\hline & & After sewerage & 31 & 89 & 120 \\
\hline & \multirow{2}{*}{$\%$} & Before sewerage & 87.4 & 12.6 & 100.0 \\
\hline & & After sewerage & 25.8 & 74.2 & 100.0 \\
\hline
\end{tabular}

${ }^{a}$ In total, $83.6 \%$ of original grouped cases correctly classified. ${ }^{\mathrm{b}}$ Cross validation was done only for those cases in the analysis. In cross validation, each case was classified by the functions derived from all cases other than that case. ${ }^{c}$ In total, $82.4 \%$ of cross-validated grouped cases were correctly classified.

\subsection{Spatio-Temporal Changes in Groundwater Quality}

In order to determine the spatial distribution of the pollutants, interpolated maps were produced based on the concentrations at the sampling points (Figure 5).

The concentration of $\mathrm{PO}_{4}{ }^{3-}$ in the year before the sewerage showed the highest values in the central areas of the municipality $(2 \mathrm{mg} / \mathrm{L}$ isoline $)$ and a decreasing trend towards the north and south of the municipality (Figure 5). This pattern showed a high similarity with the spatial distribution observed in 2011-2012. However, concentrations were above $0.5 \mathrm{mg} / \mathrm{L}$ in most parts of the municipality. Further, five years after the construction of the sewerage, in 2019, significant changes were observed. The central area of the agglomeration remained the most polluted, but there were no areas with concentrations above 2 or $3 \mathrm{mg} / \mathrm{L}$, with only a small area above $1.5 \mathrm{mg} / \mathrm{L}$. The other significant change was that the area with concentrations below the limit value had increased significantly (Figure 5). While in 2013, 
concentrations below the limit were only measured in the north and south peripheral areas of the municipality, in 2019 concentrations below the limit were found in all but the central areas of the municipality and a few small areas.
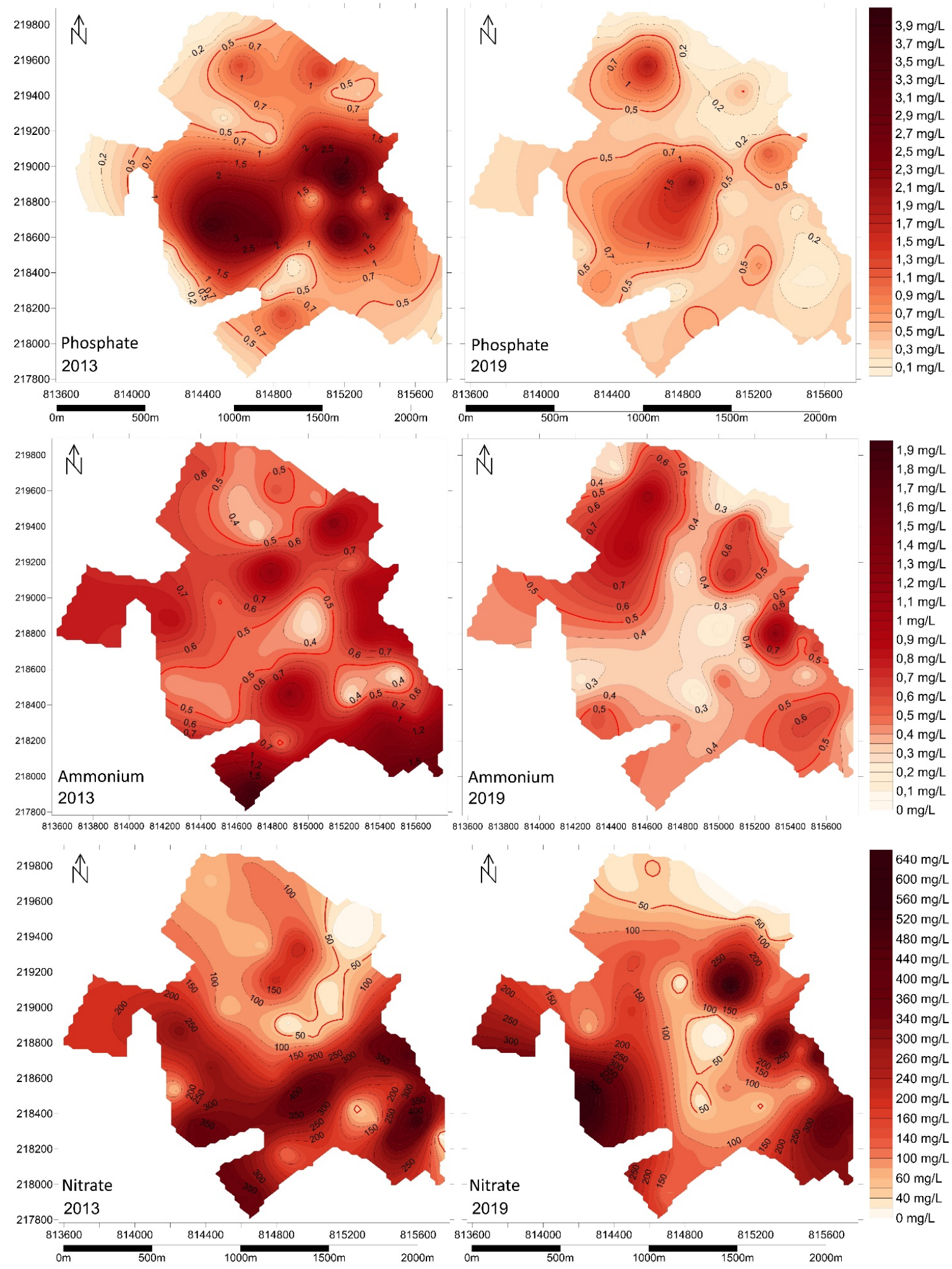

Figure 5. Spatial distribution of $\mathrm{PO}_{4}{ }^{3-}, \mathrm{NH}_{4}{ }^{+}$and $\mathrm{NO}_{3}{ }^{-}$concentration before (2013) and five years after the establishment of the sewerage network (2019). 
In 2013, the highest $\mathrm{NH}_{4}{ }^{+}$concentrations were measured in the South and East areas of the municipality $(>0.7 \mathrm{mg} / \mathrm{L})$; concentrations below $0.5 \mathrm{mg} / \mathrm{L}$ were detected in the North and Central areas (Figure 5). By 2019, the proportion of areas of the municipality where the map shows concentrations below $0.5 \mathrm{mg} / \mathrm{L}$ had increased significantly. However, concentrations above $0.2 \mathrm{mg} / \mathrm{L}$ still indicate high levels of pollution.

For $\mathrm{NO}_{3}{ }^{-}$, a very characteristic spatial distribution was observed in the reference year prior to sewerage (Figure 5). Similar to the data for 2011 and 2012, the southern areas of the municipality showed very high levels of pollution. Almost the entire area south of the centre of the municipality showed concentrations above $200 \mathrm{mg} / \mathrm{L}$, with a continuous band of concentrations above $300 \mathrm{mg} / \mathrm{L}$. In contrast, the northern part of the municipality was less polluted, but concentrations above the limit value of $50 \mathrm{mg} / \mathrm{L}$ were also measured in the majority of the area. By 2019, the north-south difference had disappeared, with a significant positive change in the central part of the area. The most polluted areas are still the South-West and South-East parts of the municipality, but their area coverage has decreased significantly (Figure 5). In parallel, the proportion of areas with concentrations below $100 \mathrm{mg} / \mathrm{L}$ has increased significantly.

In the period before the construction of the sewerage network, clear spatial differences were shown in the degree of contamination in the area of the settlement. The degree of contamination increases in the direction of local groundwater flow, which was detected for most of the parameters studied $\left(\mathrm{NH}_{4}{ }^{+}, \mathrm{NO}_{2}{ }^{-}, \mathrm{NO}_{3}{ }^{-}, \mathrm{EC}\right)$. The horizontal hydraulic gradient slopes toward the Eszteró-Canal in the southern vicinity of the settlement, which drains the area.

$\mathrm{NO}_{3}{ }^{-}$concentrations before the construction of the sewerage network showed a very significant degree of contamination in the $\mathrm{S}$ areas of the municipality. The $\mathrm{N}$ part of the settlement was less polluted, but in the vast majority of the area concentrations above the limit were measured. Wells located south had an average $\mathrm{NO}_{3}{ }^{-}$value of $429 \mathrm{mg} / \mathrm{L}$, while wells located north had an average value of $147 \mathrm{mg} / \mathrm{L}$. There were also significant differences in the EC values of groundwater wells. While the average EC value of southlocated wells was $4396 \mu \mathrm{S} / \mathrm{cm}$, the average value of north-located wells was $2476 \mu \mathrm{S} / \mathrm{cm}$. A total of $87 \%$ of the wells with $\mathrm{NH}_{4}{ }^{+}$concentrations higher than $1 \mathrm{mg} / \mathrm{L}$ were located in southern areas. Further, $62 \%$ of wells with $\mathrm{NO}_{2}{ }^{-}$concentrations lower than $0.2 \mathrm{mg} / \mathrm{L}$ were in the northern part of the municipality.

A two-step cluster analysis was performed to determine the percentage of wells we classified as "northern" and "southern" (20-20 wells) in the lower and higher contaminated cluster before and after sewering. We also examined the weight of each water chemistry parameter in the formation of the lower and higher contaminated cluster (Figure 6).

In the period 2011-2013, before sewerage, EC had the greatest weight in the formation of clusters. The second and third dominant parameters were $\mathrm{NO}_{3}{ }^{-}$and $\mathrm{NO}_{2}{ }^{-}$. Nearly $60 \%$ of all samples were in the higher contamination cluster (1), with $65.3 \%$ of these samples coming from wells located in the south. In the lower contamination group (2), $61.3 \%$ of the samples were from wells located in the north. Therefore, it can be seen that there is of course no clear line between the boundaries of the two areas, but that a transition zone is also emerging. At the same time, the analysis shows that a marked north-south difference appears. This is confirmed by the markedly different average values of the parameters of the two clusters (Figure 6). The higher contaminated cluster had an average EC value of $4396 \mu \mathrm{S} / \mathrm{cm}$ and an average $\mathrm{NO}_{3}{ }^{-}$value of $430 \mathrm{mg} / \mathrm{L}$, compared to $2476 \mu \mathrm{S} / \mathrm{cm}$ and $147 \mathrm{mg} / \mathrm{L}$ for the lower contaminated cluster.

For the 2017/2018/2019 post-sewerage database, $\mathrm{NO}_{3}{ }^{-}$and $\mathrm{EC}$ were the main clustering factors. The third most important parameter was COD. The purification processes are illustrated by the fact that, in contrast to the pre-sewerage period, more than $70 \%$ of the water samples were placed in the lower pollution cluster. Furthermore, 52.3\% of the water samples in the cluster came from wells located in the north. This shows that the differences between northern and southern wells are decreasing. The average EC value decreased for both higher and lower contaminated clusters in the post-sewerage 
period (from $4396 \mu \mathrm{S} / \mathrm{cm}$ to $4168 \mu \mathrm{S} / \mathrm{cm}$; from $2476 \mu \mathrm{S} / \mathrm{cm}$ to $2193 \mu \mathrm{S} / \mathrm{cm}$ ). An even more significant decrease was observed for $\mathrm{NO}_{3}{ }^{-}$. From $429 \mathrm{mg} / \mathrm{L}$ to $286 \mathrm{mg} / \mathrm{L}$ for the higher contaminated cluster and from $147 \mathrm{mg} / \mathrm{L}$ to $84 \mathrm{mg} / \mathrm{L}$ for the lower contaminated cluster.

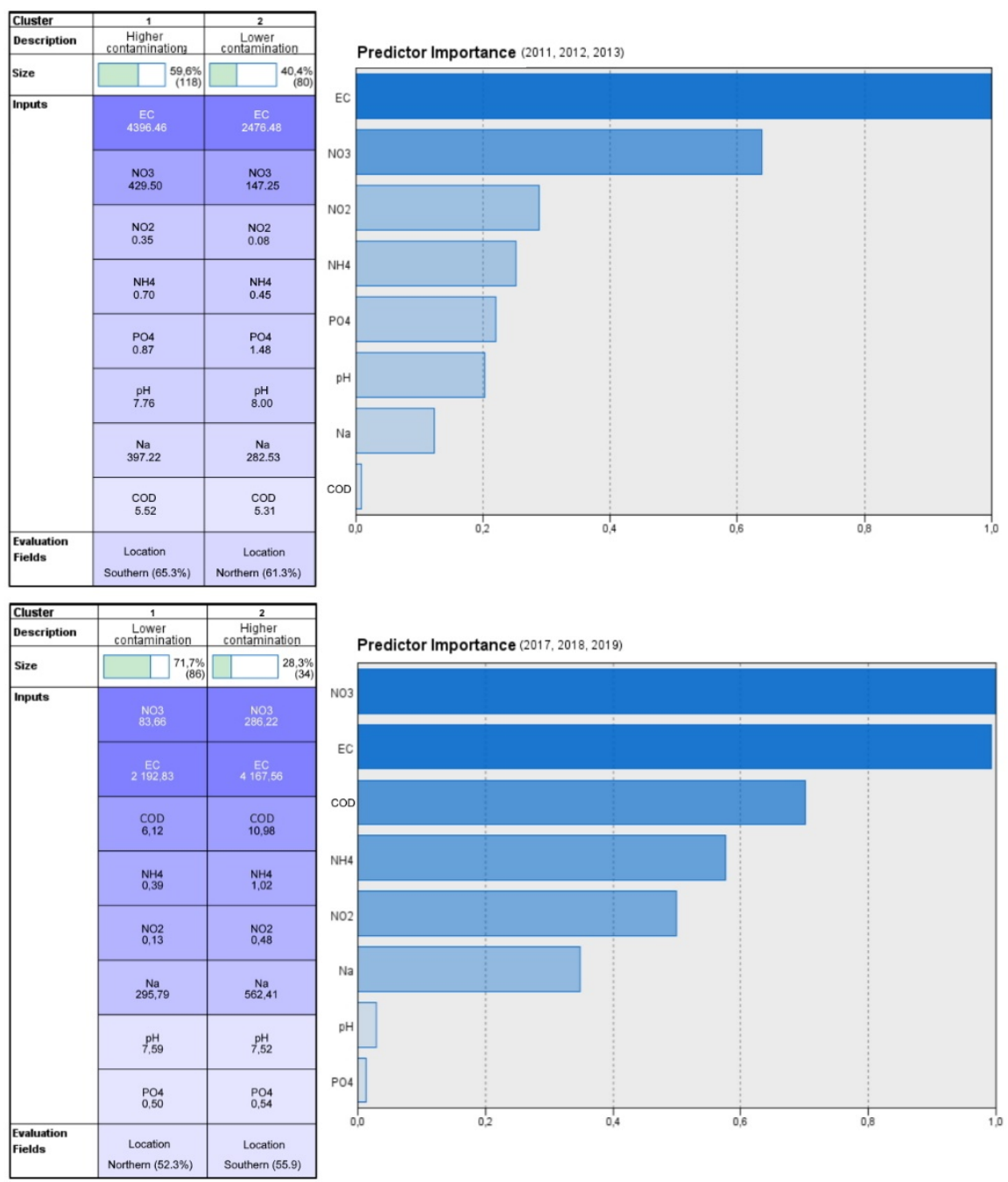

Figure 6. Results of two-step cluster analysis for data before and after the establishment of the sewerage network.

Since hierarchical cluster analysis is not suitable for large sample sizes, the results of the summer sampling before sewerage (2013) and five years after sewerage (2019) were included in the analysis. However, an important advantage of the analysis is that it does not work with a predefined number of clusters, so that grouping wells by common characteristics gives a more detailed picture. The dendograms produced by the Ward method are shown in Figure 7. Based on the results of 2013, a south-only cluster of 12 wells based on hierarchical cluster analysis was clearly defined (Figure 7). The other dominant cluster contained northern wells in $74 \%$. In addition, a third cluster was also formed the five wells of which can be found in the central part of the settlement $(17,18,24,25$, 27). In the fifth year following the establishment of the sewerage network, this clear difference between wells was eliminated with a decrease in the level of contamination, with approximately the same proportion (52-48\%) of north and south wells in the two established clusters. The decrease in the differences between northern and southern wells is associated with a decrease in pollution. 

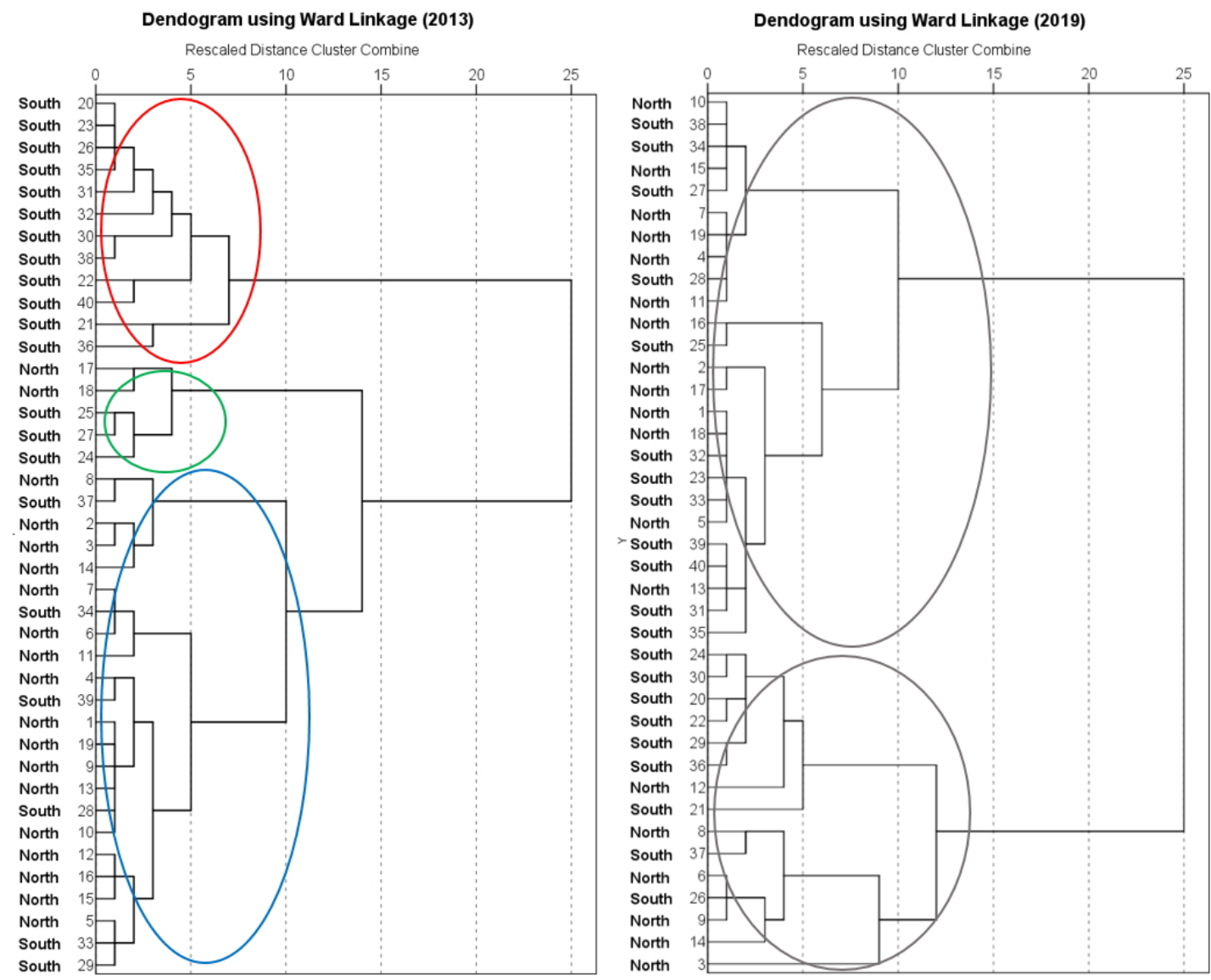

Figure 7. Ward's dendogram based on the location of sampling sites before (2013) and after (2019) the construction of the sewerage network.

\subsection{Results of Principal Component Analysis}

In order to explore the degree of monotonic relationship between the examined parameters, correlation calculations were performed with the help of SPSS 22 software (Table 3). Among the examined parameters, a significant $(p<0.001)$, strongest positive relationship was found between $\mathrm{NO}_{3}-\mathrm{EC}(\mathrm{r}=0.779)$ and a moderately strong correlation between Na-EC $(r=0.445)$ and $\mathrm{NO}_{2}-\mathrm{EC}(\mathrm{r}=0.408)$. $\mathrm{NO}_{3}-\mathrm{EC}$ and $\mathrm{Na}-\mathrm{EC}$ values were also plotted on an ordination diagram (Figure 8).

Table 3. Correlation matrix of the investigated parameters.

\begin{tabular}{ccccccccc}
\hline Parameter & $\mathbf{p H}$ & $\mathrm{EC}$ & $\mathrm{NH}_{4}{ }^{+}$ & $\mathbf{N O}_{2}{ }^{-}$ & $\mathrm{NO}_{3}{ }^{-}$ & $\mathbf{P O}_{4}{ }^{3-}$ & $\mathbf{C O D}$ & $\mathbf{N a}^{+}$ \\
\hline $\mathbf{p H}$ & 1.000 & & & & & & & \\
$\mathbf{E C}$ & $-0.115^{*}$ & 1.000 & & & & & & \\
$\mathrm{NH}_{4}{ }^{+}$ & 0.044 & $0.408^{* *}$ & 1.000 & & & & & \\
$\mathbf{N O}_{2}{ }^{-}$ & -0.044 & $0.357^{* *}$ & $0.335^{* *}$ & 1.000 & & & & \\
$\mathbf{N O}_{3}{ }^{*}$ & $-0.112^{*}$ & $0.771^{* *}$ & $0.297^{* *}$ & $0.205^{* *}$ & 1.000 & & & \\
$\mathbf{P O}_{4}{ }^{*-}$ & $0.329^{* *}$ & $0.112^{*}$ & 0.029 & -0.095 & $0.192^{* *}$ & 1.000 & & \\
$\mathbf{C O D}$ & $-0.117^{*}$ & $0.165^{* *}$ & $0.188^{* *}$ & $0.221^{* *}$ & -0.106 & 0.080 & 1.000 & \\
$\mathbf{N a}^{+}$ & -0.016 & $0.445^{* *}$ & 0.066 & $0.173^{* *}$ & $0.329^{* *}$ & -0.002 & $0.124^{*}$ & 1.000 \\
\hline
\end{tabular}

* Correlation is significant at the 0.05 level (2-tailed); ${ }^{* *}$ correlation is significant at the 0.01 level (two-tailed).

To explore the background geochemical processes, the database was subjected to principal component analysis. Since the data series did not show a normal distribution, they were normalised. The Kaiser-Meyer-Olkin test result showed a value above 0.6 and the Bartlett test result showed $p<0.001$, so the conditions for principal component analysis were met. Three principal components were identified according to the Kaiser 
criterion, explaining $65.81 \%$ of the total variance. The first principal component was formed by $\mathrm{NO}_{3}{ }^{-}$EC-Na. The second principal component was formed by COD- $\mathrm{NH}_{4}{ }^{+}-\mathrm{NO}_{2}{ }^{-}$, indicating a close relationship between organic matter degradation, ammonification and nitrification (Table 4). The third principal component was formed by $\mathrm{PO}_{4}{ }^{3-}-\mathrm{pH}$, which can be explained by the different solubility of phosphate at different $\mathrm{pH}$ values.
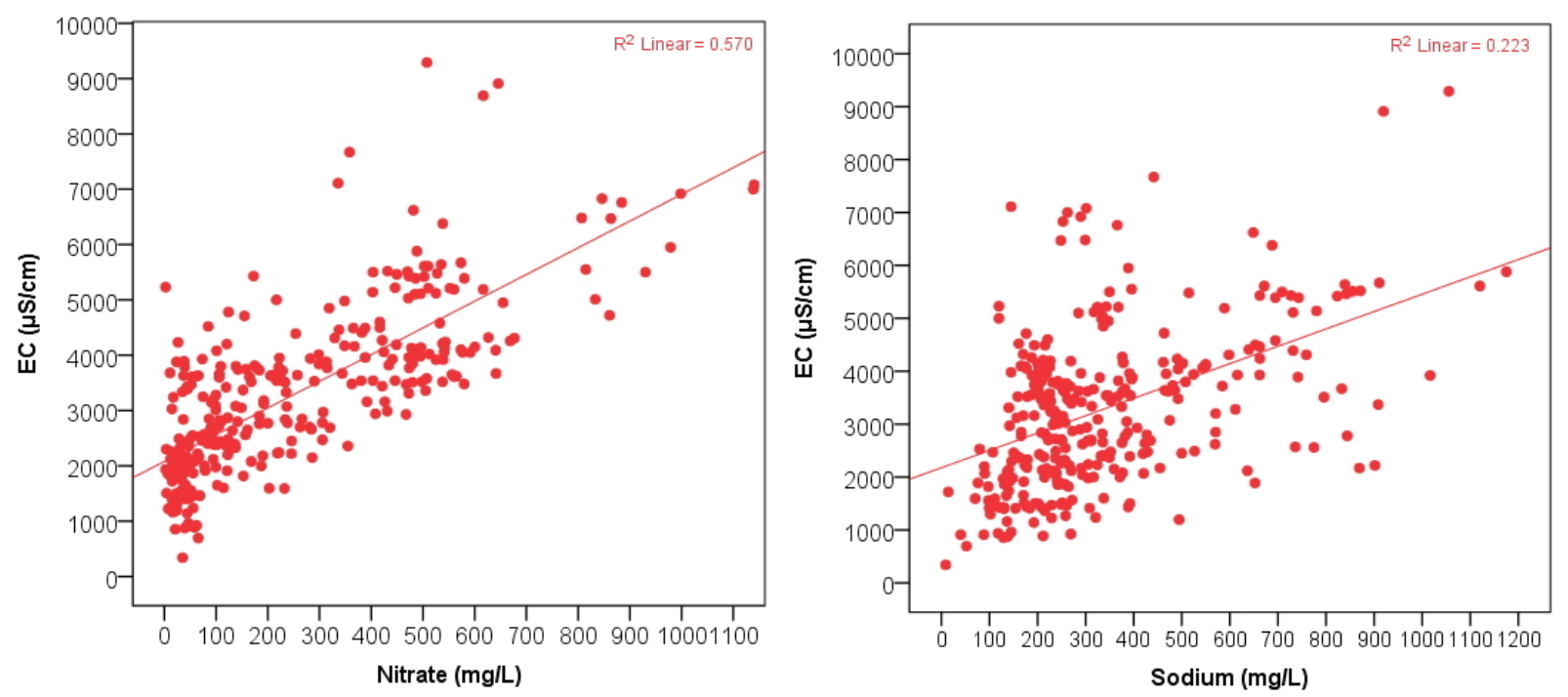

Figure 8. Scatter plot diagram for $\mathrm{EC}-\mathrm{NO}_{3}{ }^{-}$and $\mathrm{EC}-\mathrm{Na}^{+}$.

Table 4. Loadings of the variables on three significant principal components.

\begin{tabular}{cccc}
\hline & \multicolumn{3}{c}{ Rotated Component Matrix ${ }^{\mathbf{a}}$} \\
\hline \multirow{2}{*}{ Parameters } & \multicolumn{3}{c}{ Component } \\
\cline { 2 - 4 } & $\mathbf{1}$ & $\mathbf{2}$ & $\mathbf{3}$ \\
\hline $\mathrm{NO}_{3}{ }^{-}$ & $\mathbf{0 . 8 8 8}$ & -0.063 & 0.074 \\
$\mathrm{EC}$ & $\mathbf{0 . 8 7 7}$ & 0.307 & 0.021 \\
$\mathrm{Na}^{+}$ & $\mathbf{0 . 5 6 9}$ & 0.110 & -0.083 \\
$\mathrm{COD}$ & -0.108 & $\mathbf{0 . 7 4 3}$ & -0.015 \\
$\mathrm{NH}_{4}{ }^{+}$ & 0.212 & $\mathbf{0 . 7 1 7}$ & 0.147 \\
$\mathrm{NO}_{2}{ }^{-}$ & 0.255 & $\mathbf{0 . 6 5 7}$ & -0.109 \\
$\mathrm{PO}_{4}{ }^{-}$ & 0.148 & -0.052 & $\mathbf{0 . 8 1 0}$ \\
$\mathrm{pH}^{-}$ & -0.173 & 0.068 & $\mathbf{0 . 7 9 0}$
\end{tabular}

Extraction method: principal component analysis. Rotation method: varimax with Kaiser normalization. ${ }^{\text {a }}$ Rotation converged in four iterations.

Data from the wells located north and south were subjected to principal component analysis, which clearly showed the difference between the north and south wells. After the construction of the sewerage network, the size of the transition zone between groups increased (Figure 9).

\subsection{Anion and Cation Content of Groundwater}

Piper and Durov diagrams were created to understand the hydrochemical facies (Figure 10). The dominant cations and anions were $\mathrm{Ca}^{2+}$ and $\mathrm{Cl}^{-}$since the majority of the samples were classified as $\mathrm{Cl}-\mathrm{Ca}$ type and $\mathrm{SO}_{4}{ }^{*} \mathrm{Cl}-\mathrm{Ca}{ }^{*} \mathrm{Mg}$ type. The hydrochemical facies of the shallow groundwater were determined by rock dominance, evaporation and anthropogenic activities. The main source of chloride was municipal wastewater beside of geogene origin. 


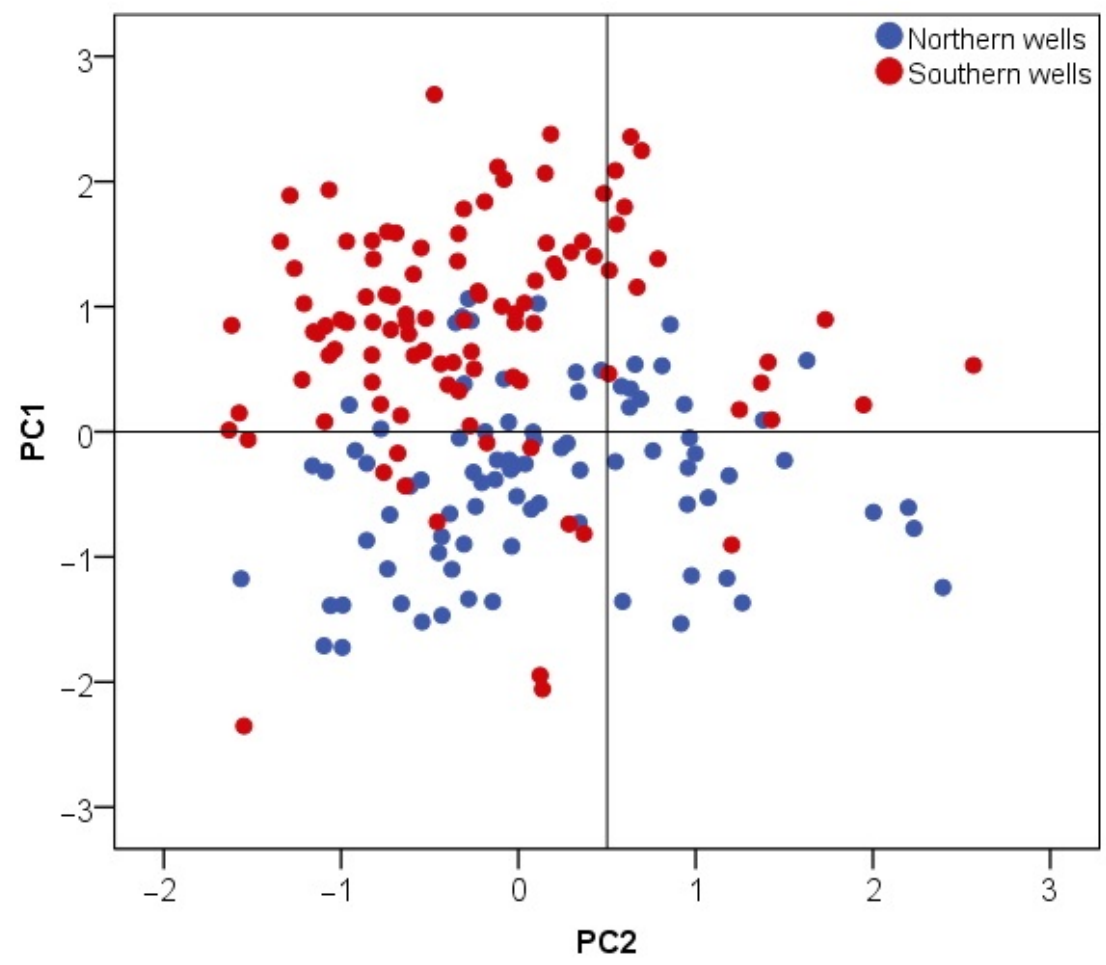

Figure 9. Bivariate plot of the scores of PCs 1 and 2 according to zone of location of the monitoring wells before sewerage.
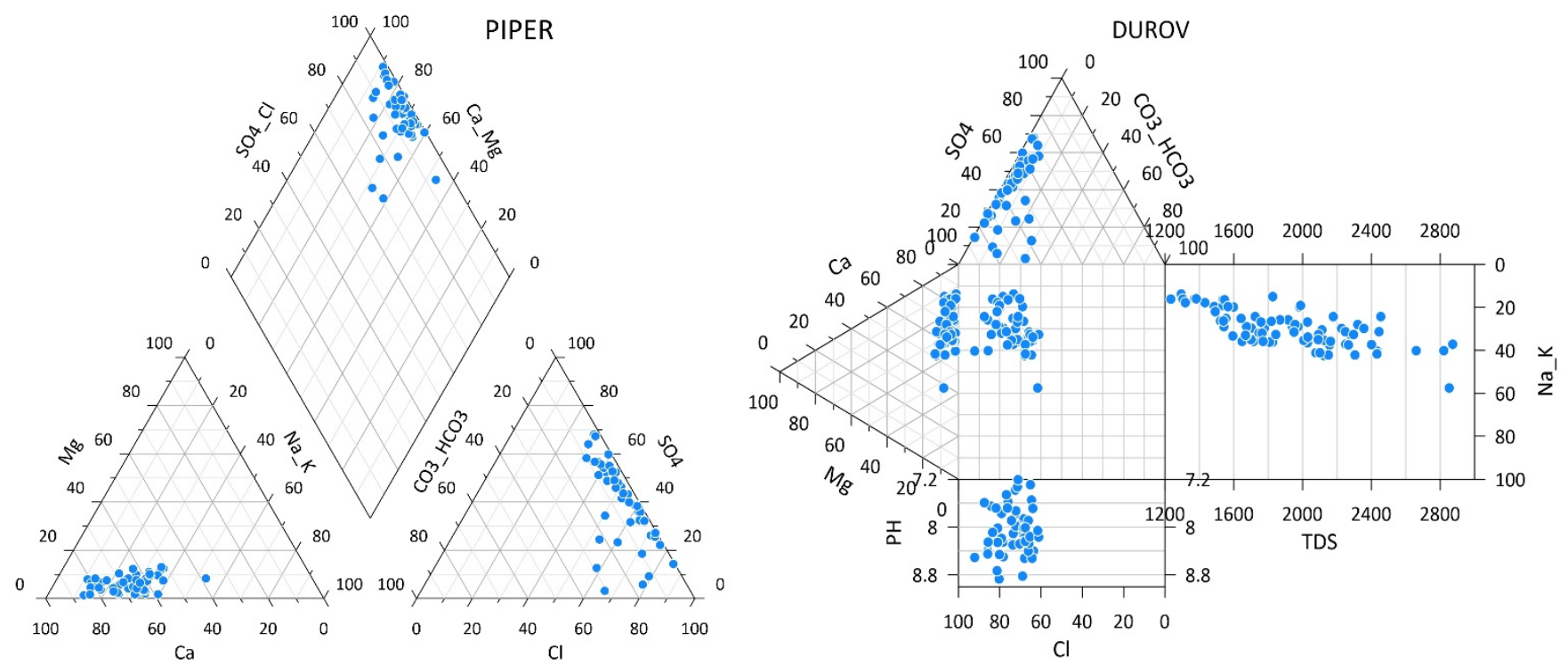

Figure 10. Piper and Durov diagrams for groundwater samples of the study area after sewerage.

\subsection{Changes in Groundwater Level after the Construction of the Sewerage Network}

Changes in the groundwater level after the construction of the sewerage network were assessed on the basis of water levels measured during the summer sampling (Figure 11). In the year preceding the establishment of the sewerage network in 2013, the groundwater level was between $88.51 \mathrm{~m}$ a.s.1. and $86.98 \mathrm{~m}$ a.s.l. The groundwater level was highest in the inner parts of the settlement, while the deepest water level could be measured in the southern areas of the settlement. 

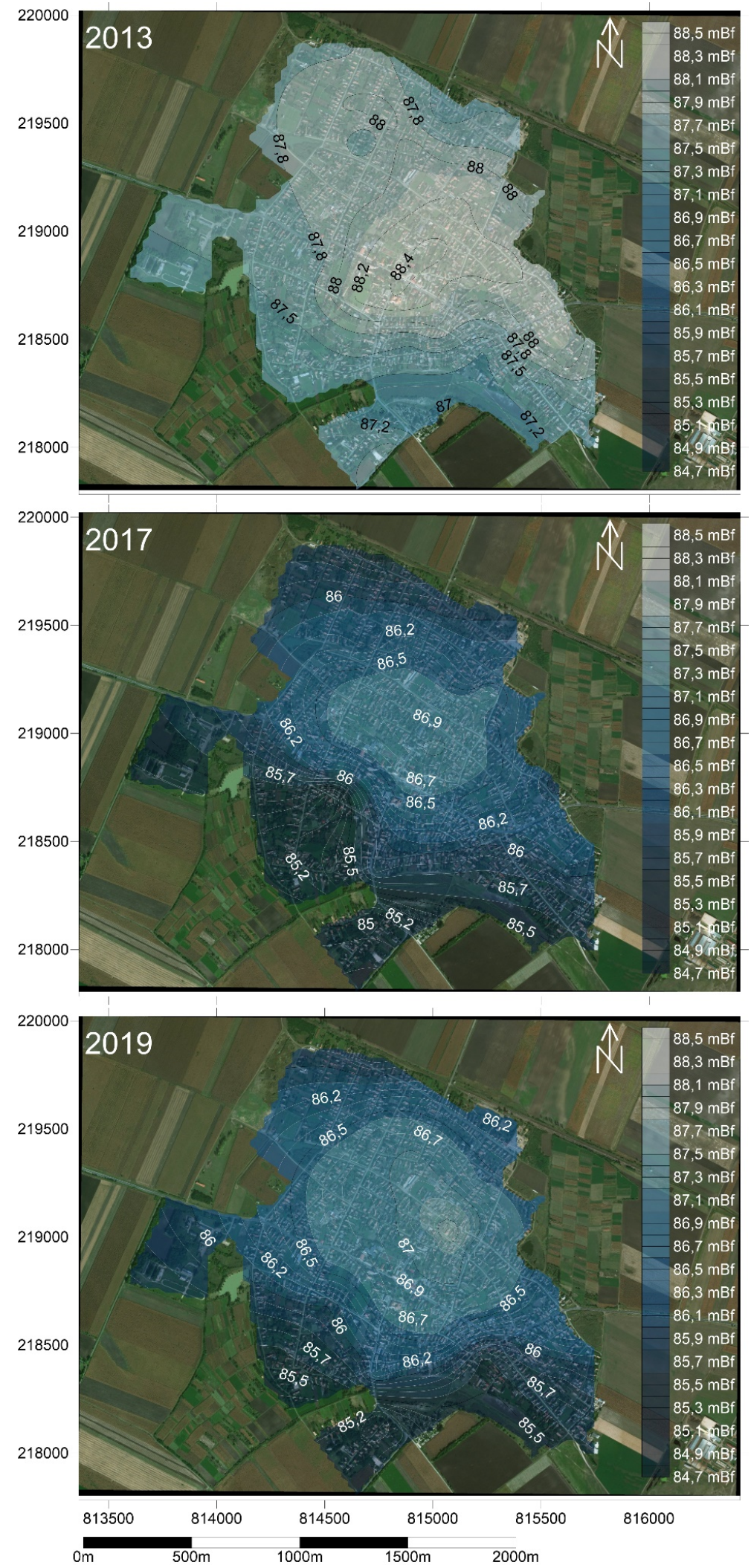

Figure 11. Groundwater table (a.s.l.) before $(2013)$ and after $(2017,2019)$ the construction of the sewerage network.

In the period after the establishment of the sewerage network, significant changes can be observed as a result of that wastewater outflow was stopped. There was a strong 
descent in groundwater levels. The average decrease in water levels in the period after the establishment of the sewerage network was 1.5 to $2 \mathrm{~m}$, which cannot be explained by changes in precipitation conditions, the reason for the decrease in water levels is clearly due to that wastewater outflow was eliminated.

We found that differences between low- and high-water levels increased after the construction of the sewerage network. While the difference between the minimum and maximum water levels was $1.53 \mathrm{~m}$ in 2013, this increased to $2.29 \mathrm{~m}$ by 2017 and was $2.15 \mathrm{~m}$ in 2019. The phenomenon can be explained by that wastewater from households made the water level in the municipality more balanced. In southern areas with low groundwater levels, the damming effect due to wastewater outflow was even stronger than in areas with higher water levels.

A significant, strong negative correlation between the groundwater data series of the period before and after the establishment of the sewerage network $(r=-0.812)$ has been demonstrated. Applying the Wilcoxon test, we showed that there was a clear background process (sewerage) behind the differences in the three-year data series. We found that by discriminant analysis water level data can be used to determine with an accuracy of $94.2 \%$ whether the water level data is derived from the period before or after the establishment of the sewerage network (Table 5).

Table 5. Classification results of the discriminant analysis for groundwater levels.

\begin{tabular}{|c|c|c|c|c|c|}
\hline \multicolumn{6}{|c|}{ Classification Results ${ }^{a, c}$} \\
\hline & & \multirow{2}{*}{ Sewerage Status } & \multicolumn{2}{|c|}{ Predicted Group Membership } & \multirow{2}{*}{ Total } \\
\hline & & & Before Sewerage & After Sewerage & \\
\hline \multirow{4}{*}{ Original } & \multirow{2}{*}{ Count } & Before sewerage & 43 & 4 & 47 \\
\hline & & After sewerage & 3 & 70 & 73 \\
\hline & \multirow{2}{*}{$\%$} & Before sewerage & 91.5 & 8.5 & 100.0 \\
\hline & & After sewerage & 4.1 & 95.9 & 100.0 \\
\hline \multirow{4}{*}{ Cross-validated $^{b}$} & \multirow{2}{*}{ Count } & Before sewerage & 43 & 4 & 47 \\
\hline & & After sewerage & 3 & 70 & 73 \\
\hline & \multirow{2}{*}{$\%$} & Before sewerage & 91.5 & 8.5 & 100.0 \\
\hline & & After sewerage & 4.1 & 95.9 & 100.0 \\
\hline
\end{tabular}

${ }^{a}$ In total, $94.2 \%$ of original grouped cases were correctly classified. ${ }^{\mathrm{b}}$ Cross validation was done only for those cases in the analysis. In cross validation, each case was classified by the functions derived from all cases other than that case. ${ }^{\mathrm{c}}$ A total of $94.2 \%$ of cross-validated grouped cases were correctly classified.

The negative effect of falling groundwater levels as a result of the construction of the sewerage network can be seen in trees drying out, subsiding houses and fracturing house walls. These processes are currently based only on observations of residents and have not yet been followed up by scientific studies, but we also consider it of paramount importance to monitor the potential negative impacts of wastewater investments.

\section{Conclusions}

Based on the results of water sampling carried out in the pre-sewerage period (2011-2013), a strong contamination of the groundwater supply of the settlement was found. Significant positive changes in the quality of groundwater were detected when the data series of the time periods prior to (2011-2013) and after (2017-2019) the establishment of the sewerage network using various geoinformatic and statistical methods. The results of the analysis of the large sample prior to (2013) and after (2017-2019) the establishment of the sewerage network showed the clear decrease of the concentration of inorganic contaminants $\left(\mathrm{NH}_{4}{ }^{+}\right.$, $\mathrm{NO}_{2}{ }^{-}, \mathrm{NO}_{3}{ }^{-}, \mathrm{PO}_{4}{ }^{3-}$ ).

Applying discriminant analysis, it can be determined with $82.4 \%$ probability whether the sample is from the period prior to or after the establishment of the sewerage network. 
On this basis, the construction of the sewerage network resulted in marked changes in the quality of groundwater wells.

In the period before sewerage, clear spatial differences were shown in the degree of contamination in the area of the settlement. We found that the degree of contamination increases in the direction of local groundwater flow, which was detected for most of the parameters studied $\left(\mathrm{NH}_{4}{ }^{+}, \mathrm{NO}_{2}{ }^{-}, \mathrm{NO}_{3}{ }^{-}, \mathrm{EC}\right)$. The results of the principal component and two-stage cluster analyses also supported the differences between the $\mathrm{N}$ and $\mathrm{S}$ areas. At the same time, of course, there is no clear line between the boundaries of the two areas, but a transitional zone is also formed. In the fifth year following the establishment of the sewerage network, this clear difference between wells was eliminated with a decrease in the level of contamination, with approximately the same proportion of north and south wells in the two established clusters.

It has also been shown that groundwater levels have decreased significantly in the post sewerage period. The average decrease of $1.5-2 \mathrm{~m}$ can be explained by the cessation of sewage outflow in the settlement. Any further decrease could increase the negative effects of the investment.

On this basis, it can be declared that the purification processes in the area have started, but at the same time, our results show that pollutants entering environment undergo a number of transformations and remain in the system for a long time. Therefore, further monitoring and environmental measures may be necessary.

Author Contributions: Conceptualization, T.M., G.S. and D.B.; methodology, T.M., G.S. and D.B.; software, T.M. and D.B.; validation, T.M., G.S. and D.B.; formal analysis, T.M.; investigation, T.M., G.S. and D.B.; resources, T.M. and G.S.; data curation, T.M. and D.B.; writing-original draft preparation, T.M., G.S. and D.B.; writing-review and editing, T.M., G.S. and D.B.; visualization, T.M. and D.B.; supervision, T.M. and G.S. All authors have read and agreed to the published version of the manuscript.

Funding: This research received no external funding.

Institutional Review Board Statement: Not applicable.

Informed Consent Statement: Not applicable.

Data Availability Statement: Not applicable.

Acknowledgments: This work was supported by the construction EFOP-3.6.3-VEKOP-16-2017-00002. The project was supported by the European Union, co-financed by the European Social Fund.

Conflicts of Interest: The authors declare no conflict of interest.

\section{References}

1. Graham, J.P.; Polizzotto, M.L. Pit latrines and their impacts on groundwater quality: A systematic review. Environ. Health Perspect. 2013, 121, 521-530. [CrossRef]

2. Richards, S.; Paterson, E.; Withers, P.J.; Stutter, M. Septic tank discharges as multi-pollutant hotspots in catchments. Sci. Total Environ. 2016, 542, 854-863. [CrossRef] [PubMed]

3. Fylypchuk, V.; Induchny, S.; Pearce, P.; Fylypchuk, L.; Martynov, S. Application of expanded polystyrene filter for tertiary treatment of domestic waste effluent in the UK. J. Water Land Dev. 2017, 35, 41-47. [CrossRef]

4. Bugajski, P.M.; Kurek, K.; Młyński, D.; Operacz, A. Designed and real hydraulic load of household wastewater treatment plants. J. Water Land Dev. 2019, 40, 155-160. [CrossRef]

5. Mester, T.; Balla, D.; Karancsi, G.; Bessenyei, É.; Szabó, G. Effects of nitrogen loading from domestic wastewater on groundwater quality. Water SA 2019, 45, 349-358. [CrossRef]

6. Heatwole, K.K.; McCray, J.E. Modeling potential vadose-zone transport of nitrogen from onsite wastewater systems at the development scale. J. Contam. Hydrol. 2007, 91, 184-201. [CrossRef] [PubMed]

7. Nemčić-Jurec, J.; Singh, S.K.; Jazbec, A.; Gautam, S.K.; Kovač, I. Hydrochemical investigations of groundwater quality for drinking and irrigational purposes: Two case studies of Koprivnica-Križevci County (Croatia) and district Allahabad (India). Sustain. Water Resour. Manag. 2017, 5, 467-490. [CrossRef]

8. Mester, T.; Szabo, G.; Bessenyei, E.; Karancsi, G.; Barkoczi, N.; Balla, D. The effects of uninsulated sewage tanks on groundwater. A case study in an eastern Hungarian settlement. J. Water Land Dev. 2017, 33, 123-129. [CrossRef] 
9. Hastuti, E.; Riyana, R.; Joy, B.; Supratman, U.; Pamekas, R. Integrated Community Onsite Sanitation System for Close Loop Faecal Management. In Proceedings of the 4th International Conference on Sustainability Science (CSS2020), Bandung, Indonesia, 8 October 2020; Volume 249, p. 01005.

10. Azzellino, A.; Colombo, L.; Lombi, S.; Marchesi, V.; Piana, A.; Andrea, M.; Alberti, L. Groundwater diffuse pollution in functional urban areas: The need to define anthropogenic diffuse pollution background levels. Sci. Total Environ. 2019, 656, 1207-1222. [CrossRef]

11. Machiwal, D.; Jha, M.K. Identifying sources of groundwater contamination in a hard-rock aquifer system using multivariate statistical analyses and GIS-based geostatistical modeling techniques. J. Hydrol. Reg. Stud. 2015, 4, 80-110. [CrossRef]

12. Kringel, R.; Rechenburg, A.; Kuitcha, D.; Fouépé, A.; Bellenberg, S.; Kengne, I.M.; Fomo, M.A. Mass balance of nitrogen and potassium in urban groundwater in Central Africa, Yaounde/Cameroon. Sci. Total Environ. 2016, 547, 382-395. [CrossRef]

13. Adimalla, N.; Qian, H.; Tiwari, D.M. Groundwater chemistry, distribution and potential health risk appraisal of nitrate enriched groundwater: A case study from the semi-urban region of South India. Ecotoxicol. Environ. Saf. 2020, 207, 111277. [CrossRef] [PubMed]

14. Janža, M.; Prestor, J.; Pestotnik, S.; Jamnik, B. Nitrogen mass balance and pressure impact model applied to an urban aquifer. Water 2020, 12, 1171. [CrossRef]

15. Wakida, F.T.; Lerner, D.N. Non-agricultural sources of groundwater nitrate: A review and case study. Water Res. 2005, 39, 3-16. [CrossRef] [PubMed]

16. Koda, E.; Sieczka, A.; Osinski, P. Ammonium Concentration and Migration in Groundwater in the Vicinity of Waste Management Site Located in the Neighborhood of Protected Areas of Warsaw, Poland. Sustainability 2016, 8, 1253. [CrossRef]

17. Simmons, R.C.; Gold, A.J.; Groffman, P.M. Nitrate dynamics in riparian forests: Groundwater studies. J. Environ. Qual. 1992, 21, 659-665. [CrossRef]

18. Moore, K.B.; Ekwurzel, B.; Esser, B.K.; Hudson, G.B.; Moran, J.E. Sources of groundwater nitrate revealed using residence time and isotope methods. Appl. Geochem. 2006, 21, 1016-1029. [CrossRef]

19. Zhang, Q.; Qian, H.; Xu, P.; Li, W.; Feng, W.; Liu, R. Effect of hydrogeological conditions on groundwater nitrate pollution and human health risk assessment of nitrate in Jiaokou Irrigation District. J. Clean. Prod. 2021, 298, 126783. [CrossRef]

20. Huang, G.; Liu, C.; Zhang, Y.; Chen, Z. Groundwater is important for the geochemical cycling of phosphorus in rapidly urbanized areas: A case study in the Pearl River Delta. Environ. Pollut. 2020, 260, 114079. [CrossRef]

21. Mittal, A.; Singh, R.; Chakma, S.; Goel, G. Permeable reactive barrier technology for the remediation of groundwater contaminated with nitrate and phosphate resulted from pit-toilet leachate. J. Water Process. Eng. 2020, 37, 101471. [CrossRef]

22. Horváth, E. Soil and Groundwater Protection; Digital Textbook Library; TÁMOP: Hungary, Budapest, 2011 ; Volume 4.

23. Foster, S.S.D. The interdependence of groundwater and urbanisation in rapidly developing cities. Urban Water 2001, 3, 185-192. [CrossRef]

24. Wijnen, M.; Augeard, B.; Hiller, B.; Ward, C.; Huntjens, P. Managing the Invisible: Understanding and Improving Groundwater Governance. Available online: https:/ / openknowledge.worldbank.org/handle/10986/17228 (accessed on 11 July 2021).

25. Jurgens, B.C.; Fram, M.S.; Rutledge, J. Identifying areas of degrading and improving groundwater-quality conditions in the State of California, USA, 1974-2014. Environ. Monit. Assess. 2020, 192, 1-23. [CrossRef] [PubMed]

26. Kuzichkin, O.R.; Romanov, R.V.; Dorofeev, N.V.; Grecheneva, A.V.; Vasilyev, G.S. The organisation of control over non-centralized water supply under the risk of groundwater dynamics disturbance in karst areas. J. Water Land Dev. 2020, 47, 113-124.

27. Judeh, T.; Bian, H.; Shahrour, I. GIS-Based Spatiotemporal Mapping of Groundwater Potability and Palatability Indices in Arid and Semi-Arid Areas. Water 2021, 13, 1323. [CrossRef]

28. Khorasani, H.; Kerachian, R.; Aghayi, M.M.; Zahraie, B.; Zhu, Z. Assessment of the impacts of sewerage network on groundwater quantity and nitrate contamination: Case study of Tehran. In World Environmental and Water Resources Congress 2020: Groundwater, Sustainability, Hydro-Climate/Climate Change, and Environmental Engineering; American Society of Civil Engineers: Reston, VA, USA, 2020; pp. 53-66.

29. Mester, T.; Balla, D.; Szabó, G. Assessment of Groundwater Quality Changes in the Rural Environment of the Hungarian Great Plain Based on Selected Water Quality Indicators. Water Air Soil Pollut. 2020, 231, 1-14. [CrossRef]

30. Xiong, G.; An, Q.; Fu, T.; Chen, G.; Xu, X. Evolution analysis and environmental management of intruded aquifers of the Dagu River Basin of China. Sci. Total Environ. 2020, 719, 137260. [CrossRef] [PubMed]

31. Ghanem, M.; Ahmad, W.; Keilani, Y.; Sawaftah, F.; Schelter, L.; Schuettrumpf, H. Spring water quality in the central West Bank, Palestine. J. Asian Earth Sci. X 2021, 5, 100052.

32. Zichar, M. Geovisualization-related issues with cognitive aspects. In Proceedings of the 2013 IEEE 4 th International Conference on Cognitive Infocommunications (CogInfoCom), Budapest, Hungary, 2-5 December 2013; pp. 503-508.

33. Jha, M.K.; Shekhar, A.; Jenifer, M.A. Assessing groundwater quality for drinking water supply using hybrid fuzzy-GIS-based water quality index. Water Res. 2020, 179, 115867. [CrossRef]

34. Patil, V.B.B.; Pinto, S.M.; Govindaraju, T.; Hebbalu, V.S.; Bhat, V.; Kannanur, L.N. Multivariate statistics and water quality index (WQI) approach for geochemical assessment of groundwater quality-A case study of Kanavi Halla Sub-Basin, Belagavi, India. Environ. Geochem. Health 2020, 42, 2667-2684. [CrossRef] [PubMed] 
35. Fang, Y.; Zheng, T.; Zheng, X.; Peng, H.; Wang, H.; Xin, J.; Zhang, B. Assessment of the hydrodynamics role for groundwater quality using an integration of GIS, water quality index and multivariate statistical techniques. J. Environ. Manag. 2020, 273, 111185. [CrossRef]

36. Güler, C.; Thyne, G.D.; McCray, J.E.; Turner, K.A. Evaluation of graphical and multivariate statistical methods for classification of water chemistry data. Hydrogeol. J. 2002, 10, 455-474. [CrossRef]

37. Demirel, Z.; Güler, C. Hydrogeochemical evolution of groundwater in a Mediterranean coastal aquifer, Mersin-Erdemli basin (Turkey). Environ. Geol. 2006, 49, 477-487. [CrossRef]

38. Cloutier, V.; Lefebvre, R.; Therrien, R.; Savard, M.M. Multivariate statistical analysis of geochemical data as indicative of the hydrogeochemical evolution of groundwater in a sedimentary rock aquifer system. J. Hydrol. 2008, 353, 294-313. [CrossRef]

39. Yidana, S.M.; Banoeng-Yakubo, B.; Akabzaa, T.M. Analysis of groundwater quality using multivariate and spatial analyses in the Keta basin, Ghana. J. Afr. Earth Sci. 2010, 58, 220-234. [CrossRef]

40. Lin, C.Y.; Abdullah, M.H.; Praveena, S.M.; Yahaya AH, B.; Musta, B. Delineation of temporal variability and governing factors influencing the spatial variability of shallow groundwater chemistry in a tropical sedimentary island. J. Hydrol. 2012, 432, 26-42. [CrossRef]

41. Farsang, A.; Fejes, I.; Tóth, T.M. Integrated evaluation of urban groundwater hydrogeochemistry in context of fractal behaviour of groundwater level fluctuations. Hydrol. Sci. J. 2017, 62, 1216-1229. [CrossRef]

42. Hungarian Central Statistical Office (HSCO). 2020. Available online: https://www.ksh.hu/stadat_files/kor/hu/kor0067.html (accessed on 11 July 2021).

43. Koudelak, P.; West, S. Sewerage network modelling in Latvia, use of InfoWorks CS and Storm Water Management Model 5 in Liepaja city. Water Environ. J. 2008, 22, 81-87. [CrossRef]

44. Gil, B.; Wrona, R.; Kawczyński, A. Sewerage network analysis for damage vulnerability in one of cities in the Upper Silesia. J. Civ. Eng. Environ. Archit. 2015, 62, 65-79. [CrossRef]

45. Hungarian Central Statistical Office (HSCO). 2021. Available online: https://nyilvantarto.hu/hu/statisztikak?stat=kozerdeku (accessed on 11 July 2021).

46. Rónai ABonczán, B.; János, E.; Kőrössy, L.; Szepesházy, K.; Ubancsek, J. Geological atlas of the Great Hungarian Plain, Püspökladány (in Hungarian); Hungarian State Geological Institute: Budapest, Hungary, 1980; p. 20.

47. Michéli, E.; Fuchs, M.; Hegymegi, P.; Stefanovits, P. Classification of the major soils of Hungary and their correlation with the World Reference Base for Soil Resources (WRB). Agrokémia És Talajt. 2006, 55, 19-28. [CrossRef]

48. Balla, D.; Novák, T.J.; Zichar, M. Approximation of the WRB reference group with the reapplication of archive soil databases. Acta Univ. Sapientiae Agric. Environ. 2016, 8, 27-38. [CrossRef]

49. Apollaro, C.; Vespasiano, G.; Muto, F.; De Rosa, R.; Barca, D.; Marini, L. Use of mean residence time of water, flowrate, and equilibrium temperature indicated by water geothermometers to rank geothermal resources. Application to the thermal water circuits of Northern Calabria. J. Volcanol. Geotherm. Res. 2016, 328, 147-158. [CrossRef]

50. Babiker, I.S.; Mohamed, M.A.; Hiyama, T. Assessing groundwater quality using GIS. Water Resour. Manag. 2007, 21, 699-715. [CrossRef]

51. Adimalla, N.; Taloor, A.K. Hydrogeochemical investigation of groundwater quality in the hard rock terrain of South India using Geographic Information System (GIS) and groundwater quality index (GWQI) techniques. Groundw. Sustain. Dev. 2020, 10, 100288. [CrossRef]

52. Aravinthasamy, P.; Karunanidhi, D.; Subramani, T.; Roy, P.D. Demarcation of groundwater quality domains using GIS for best agricultural practices in the drought-prone Shanmuganadhi River basin of South India. Environ. Sci. Pollut. Res. 2021, 28, 18423-18435. [CrossRef]

53. Makki, Z.F.; Zuhaira, A.A.; Al-Jubouri, S.M.; Al-Hamd, R.K.S.; Cunningham, L.S. GIS-based assessment of groundwater quality for drinking and irrigation purposes in central Iraq. Environ. Monit. Assess. 2021, 193, 1-27. [CrossRef] [PubMed]

54. Balla, D.; Zichar, M.; Tóth, R.; Kiss, E.; Karancsi, G.; Mester, T. Geovisualization techniques of spatial environmental data using different visualization tools. Appl. Sci. 2020, 10, 6701. [CrossRef]

55. Adhikary, P.P.; Chandrasekharan, H.; Chakraborty, D.; Kamble, K. Assessment of groundwater pollution in West Delhi, India using geostatistical approach. Environ. Monit. Assess. 2009, 167, 599-615. [CrossRef]

56. Delhomme, J. Kriging in the hydrosciences. Adv. Water Resour. 1978, 1, 251-266. [CrossRef]

57. Jolliffe, I.T. Principal Component Analysis, 2nd ed.; Springer: New York, NY, USA, 2002.

58. Fisher, R.A. The use of multiple measurements in taxonomic problems. Ann. Eugen. 1936, 7, 179-188. [CrossRef]

59. Adekunle, I.M.; Adetunji, M.T.; Gbadebo, A.M.; Banjoko, O.B. Assessment of groundwater quality in a typical rural settlement in Southwest Nigeria. Int. J. Environ. Res. Public Health 2007, 4, 307-318. [CrossRef]

60. Khan, A.; Khan, H.H.; Umar, R. Impact of land-use on groundwater quality: GIS-based study from an alluvial aquifer in the western Ganges basin. Appl. Water Sci. 2017, 7, 4593-4603. [CrossRef]

61. Muzenda, F.; Masocha, M.; Misi, S.N. Groundwaterquality assessment using a water quality index and GIS: A case of Ushewokunze Settlement, Harare, Zimbabwe. Phys. Chem. Earth 2019, 112, 134-140. [CrossRef]

62. Celestino, A.E.M.; Leal, J.A.R.; Cruz, D.A.M.; Vargas, J.T.; De Lara Bashulto, J.; Ramírez, J.M. Identification of the hydrogeochemical processes and assessment of groundwater quality, using multivariate statistical approaches and water quality index in a wastewater irrigated region. Water 2019, 11, 1702. [CrossRef] 